\title{
Distinct gene loci control the host response to influenza H1N1 virus infection in a time-dependent manner
}

Tatiana Nedelko ${ }^{1}$, Heike Kollmus ${ }^{1}$, Frank Klawonn ${ }^{2,3}$, Sabine Spijker ${ }^{5}$, Lu Lu ${ }^{4,6}$, Manuela Heßman ${ }^{1,7}$, Rudi Alberts ${ }^{1}$, Robert W. Williams ${ }^{5}$ and Klaus Schughart ${ }^{1 *}$

\begin{abstract}
Background: There is strong but mostly circumstantial evidence that genetic factors modulate the severity of influenza infection in humans. Using genetically diverse but fully inbred strains of mice it has been shown that host sequence variants have a strong influence on the severity of influenza A disease progression. In particular, C57BL/6J, the most widely used mouse strain in biomedical research, is comparatively resistant. In contrast, $\mathrm{DBA} / 2 \mathrm{~J}$ is highly susceptible.

Results: To map regions of the genome responsible for differences in influenza susceptibility, we infected a family of 53 BXD-type lines derived from a cross between C57BL/6J and DBA/2J strains with influenza A virus (PR8, H1N1). We monitored body weight, survival, and mean time to death for 13 days after infection. Qivr5 (quantitative trait for influenza virus resistance on chromosome 5) was the largest and most significant QTL for weight loss. The effect of Qivr5 was detectable on day 2 post infection, but was most pronounced on days 5 and 6 . Survival rate mapped to Qivr5, but additionally revealed a second significant locus on chromosome 19 (Qivr19). Analysis of mean time to death affirmed both Qivr5 and Qivr19. In addition, we observed several regions of the genome with suggestive linkage. There are potentially complex combinatorial interactions of the parental alleles among loci. Analysis of multiple gene expression data sets and sequence variants in these strains highlights about 30 strong candidate genes across all loci that may control influenza A susceptibility and resistance.
\end{abstract}

Conclusions: We have mapped influenza susceptibility loci to chromosomes 2, 5, 16, 17, and 19. Body weight and survival loci have a time-dependent profile that presumably reflects the temporal dynamic of the response to infection. We highlight candidate genes in the respective intervals and review their possible biological function during infection.

\section{Background}

Influenza A virus represents a major health threat to humans. The $1918 \mathrm{H} 1 \mathrm{~N} 1$ pandemic caused at about 30 to 50 million deaths [1]. Seasonal influenza epidemics cause high economic loss, morbidity and deaths every year [2]. The course and outcome of an influenza A virus infection is influenced by viral and host factors. Host risk factors, like obesity or pregnancy, became evident during the recent swine flu pandemics $[3,4]$.

\footnotetext{
*Correspondence: kls@helmholtz-hzi.de

'Department of Infection Genetics, Helmholtz Centre for Infection Research and University of Veterinary Medicine Hannover, 38124, Braunschweig, Germany

Full list of author information is available at the end of the article
}

Furthermore, genetic factors in humans associated with a higher susceptibility to influenza infections and severe disease outcome have been suspected for the 1918 pandemics, as well as the H5N1 human infections [5-7]. Recently, the importance of IFITM3 as a crucial factor for host susceptibility has been demonstrated in mice and humans [8].

The importance of host factors to host susceptibility and resistance has been demonstrated clearly in animal models. We and others have shown in mouse infection models that the susceptibility of the host to influenza A infection strongly depends on the genetic background [9-17]. In particular, DBA/2J mice are highly susceptible to many influenza A virus subtypes, including those that

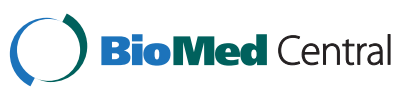


were directly derived from human isolates without prior adaptation to the mouse $[9,13,16-18]$. In contrast, C57BL/6J mice are more resistant. After infection with mouse-adapted H1N1 (PR8M virus), DBA/2J mice loss weight very rapidly and die within $5-7$ days post infection (p.i.), whereas C57BL/6J mice loss weight until days 6-8 after infection and regain their initial weight by 14 days p.i. $[9,18]$. Viral load in the lungs of DBA/2J infected mice is much higher and lung pathology is very severe compared to infected C57BL/6J mice. Also, the production of chemokines and cytokines is much higher in DBA/2J mice $[9,18]$.

However, the genomic regions that are responsible for the differential response after infection with H1N1 have not been determined. Therefore, we used a large family of BXD type recombinant inbred strains generated by crossing C57BL/6J (resistant) to DBA/2J (susceptible) to map genetic loci that modulate disease severity. The BXD genetic reference population (GRP) is made up of a set of progeny strains, each with a defined and fixed genetic architecture. It is one of the largest families of strains, consisting of about 80 fully inbred strains $[19,20]$ available from the Jackson Laboratory and a new set of 80 additional lines that are still in production at the University of Tennessee. Individuals within each single strain are essentially isogenic (except for the sex chromosomes) and genotypes for the entire family, including most of the new strains, are known [21]. Genetic variation among this family has be exploited extensively in the past to systematically study the genetics of many traits (for examples of phenotypes see the GeneNetwork database [22]).

Here, we infected over 50 of the BXD strains with influenza A H1N1 virus and monitored body weight, survival, and mean time to death for the following 13 days post infection. We identified two significant and several suggestive loci peaks for all three traits. All showed a time-dependent appearance. Data mining of the intervals revealed several candidate genes, several of which may be important for the host response to influenza A virus infection.

\section{Results}

Susceptibility to influenza A virus after experimental infection of BXD mouse strains is highly variable

We infected 53 recombinant inbred strains of the BXD population plus the parental strains C57BL/6J, DBA/2J and B6D2F1 mice with mouse-adapted $\mathrm{H} 1 \mathrm{~N} 1$ virus (PR8M, H1N1 [18]) and followed body weight and survival over the next 13 days. Mice that lost more than $25 \%$ of their starting weight were sacrificed and also recorded as dead. After infection, body weight changes were highly variable between the BXD strains over the period of 13 days post infection (Figure 1, Additional file 1: Table S1). Similarly, survival rates (Additional file 2: Figure S1A, B) and mean time to death (MTTD; Additional file 2: Figure S1C) were highly variable between the different BXD strains. Furthermore, the trait percent survival showed a strain-dependent progression over time.

For body weight loss and survival, three different phenotypic response groups can be defined (Figure 1). In the first (Figure 1A), all infected mice within a strain survived, in the second (Figure 1B) a majority but not all individuals within a strain survived, and in the third group (Figure $1 C$ ), a majority died. Most remarkably, in the first group four strains-BXD9, BXD13, BXD43, BXD97-were highly resistant indicating that the infection may not cause any major pathology (Figure 1A). In contrast, BXD28 belonging to the third group, lost body weight much more rapidly than even the highly susceptible DBA/2J parent (Figure 1C). These results illustrate a large variation of responses within the BXD family.

By day 7 p.i., all infected mice had succumbed to infection in 11 strains, whereas 14 others exhibited more limited mortality (Additional file 2: Figure S1A). The incidence of mortality increased in some strains from day 8 p.i. through day 11 but not thereafter (Additional file 2: Figure S1B). For the MTTD phenotype, 17 strains showed no mortality after infection, similar to the resistant C57BL/6J parent. Three strains-BXD28, BXD18, BXD103-exhibited a MTTD that was even shorter than for the susceptible DBA/2J parent (Additional file 2: Figure S1C). Although this study was conducted over a period of approximately three years, and although mice were received from different sources and different experimenters performed the infection experiments, we did not note any significant influence of these potential confounds and cofactors.

Principal Component Analysis (PCA) of strain mean body weight loss from day 1 until day 7 was carried out to reduce the number and redundancy of related measurements, as well as to evaluate whether this set of measurements can be broken down into statistically and genetically independent processes. This analysis revealed one major component, PC1 that explains most of the weight loss among strains (more than $80 \%$, see Additional file 3 : Figure S2). This component corresponds to differences in loss from day 3 to 7 p.i. (Figure 2). In contrast, PC2 accounts for only about $10 \%$ of the variance in weight loss (Additional file 3: Figure S2). This component corresponds only to very early weight loss after virus inoculation, on days 1 and 2 p.i.(Figure 2), well before any appreciable virus replication has occurred. Thus, $\mathrm{PC} 2$ is highly likely to be a technical, but still interesting effect associated with the stressful procedure of intranasal inoculation and full anesthesia. PC1 most likely reflects the biologically relevant variation among strains in response to viral replication. 


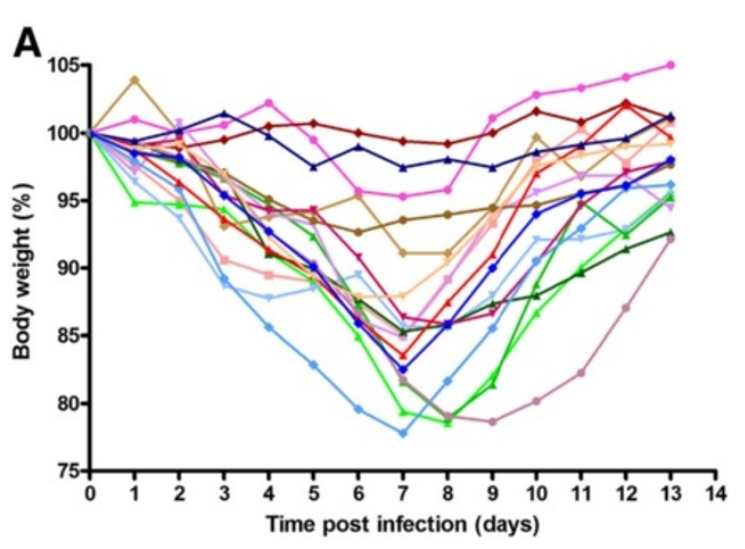

- BXD1 ( $n=5)$

$\div \operatorname{BXD} 21(n=4)$

- BXD39 $(n=8)$

$\rightarrow \operatorname{BXD98}(n=4)$

$\rightarrow$ BXD43 $(n=7)$

- BXD96 $(n=4)$

- BXD42 $(n=4)$

$\rightarrow \operatorname{BXD9}(n=5)$

$\rightarrow \operatorname{BXD} 13(n=6)$

- BXD11 $(n=8)$

$\rightarrow \operatorname{BXD79}(n=5)$

$\rightarrow \operatorname{BXD100}(n=5)$

$\rightarrow \operatorname{BXD87}(n=5)$

- BXD75 $(n=4)$

- BXD97 $(n=4)$

- BXD8 ( $n=8)$

$\rightarrow$ C57BL/6J $(n=39)$

B

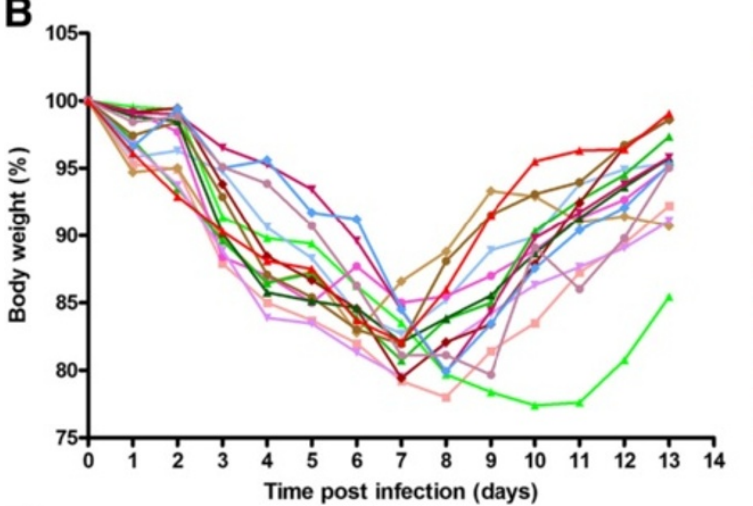

- BXD32 ( $n=7)$

$\approx \operatorname{BXD5}(n=4)$

- BXD61 ( $n=6)$

$\rightarrow$ BXD2 $(n=5)$

$\rightarrow \operatorname{BXD20}(n=5)$

$\mp$ BXD69 $(n=5)$

$\rightarrow \operatorname{BXD60}(n=5)$

$\rightarrow$ BXD71 (n=5)

$\rightarrow$ BXD84 (n=5)

- BXD67 ( $n=5)$

$\rightarrow \operatorname{BXD92}(n=5)$

$\rightarrow \operatorname{BXD} 23(n=9)$

$\rightarrow \operatorname{BXD65}(n=8)$

- B6D2F1 ( $n=29)$

C

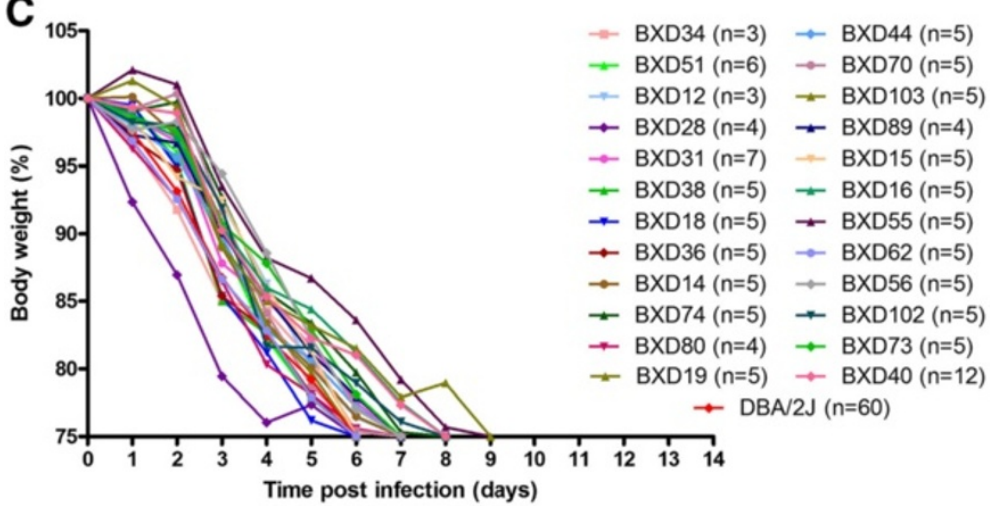

Figure 1 BXD strains exhibit variable kinetics of weight loss and survival after infection with Influenza A virus. Mice from 53 BXD and parental strains were infected intra-nasally with $2 \times 10^{3} \mathrm{FFU}$ of PR8 virus. Weight loss and survival of infected mice was followed over a period of 13 days. Mortality includes mice that were sacrificed because they had lost more than $25 \%$ of body weight. Three phenotypic groups can be distinguished: in the first group (A), all infected mice within a given BXD strain survived, in the second group (B) less than $50 \%$ of infected mice within a given BXD strain died, in the third group (C), more than $50 \%$ of infected mice within a given BXD strain died. From the weight loss curve of the second and third group it also becomes obvious that non-surviving mice were all approaching the $75 \%$ body weight loss endpoint before dying.

Analysis of body weight loss revealed a significant QTL on chromosome 5 and several suggestive QTLs with time-dependent effects

We mapped body weight loss following infection day by day. For purposes of analysis, body weights of mice that had died or that were euthanized were assigned a weight equal to $75 \%$ of their initial weight. It should be noted that mice which died continuously lost weight and were close to $75 \%$ body weight loss before they were found dead (Figure 1B, C). After day 7, surviving mice started to gain weight (Figure 1A, B). For this reason, we limited our analyses of body weight traits to the period of day 1 to day 7 p.i. in order to avoid mixing data from dead with recovering mice. Interval mapping of body weight 


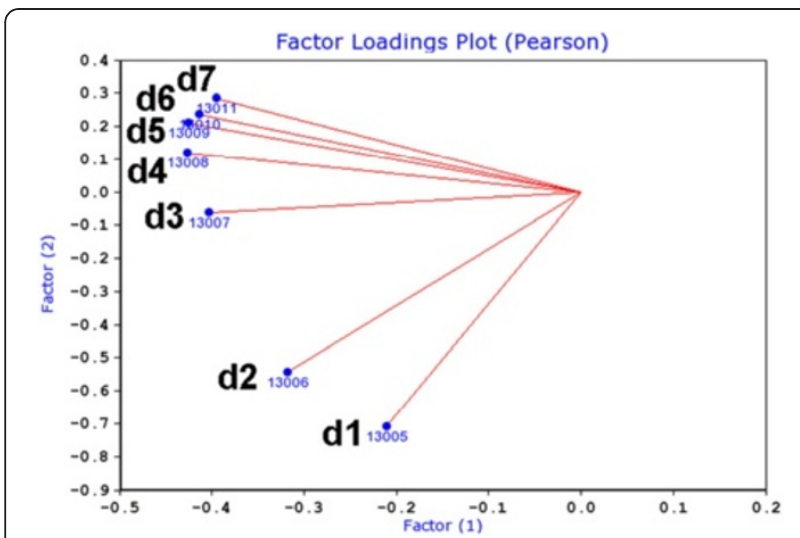

Figure 2 Principal component analysis of all body weight traits reveals two distinct groups. PCA loading plot of principal components PC1 and PC2 (Supplement Figure 2) for body weight traits form day 1 to day 7 p.i. shows two distinct groups. The variation of body weight loss at day 3 to day 7 (ID 13007 to ID 13011) are mainly represented by factor 1 . On the other hand, variation of body weight loss at day 1 (ID 13005) and 2 (ID 13006) are most likely explained by factor 2 .

loss detected a significant time-dependent locus on chromosome 5 that we named 'QTL for influenza virus resistance on chromosome 5' (Qivr5) adopting the nomenclature proposed by [12]. This QTL exhibited genome-wide significance on days 5 (LRS: 19.0, effect size: $30 \%$ ) and 6 (LRS: 19.4, effect size: 31\%, Figure 3). However, the effect of Qivr5, although weaker, can also be detected on days 2, 3, and 4 and 7 (Figure 3). Most interestingly; the resistance allele at Qivr5 is inherited from the nominally sensitive DBA/2J parental strain, illustrating the genetic complexity of the influenza response. Suggestive loci (LRS values between 10 and 15) map to chromosomes 2, 6, 9, proximal and distal 16 , and chromosome 17. The effect of these loci was also time-dependent (Figure 3A-G).

Another suggestive QTL peak was found on chromosome 10 on day 1 (LRS: 14.1, effect size: 23\%, Figure 3A). Its effect is lower at day 2 and not apparent at later days. These observations are in accordance with the PCA (Figure 2) that reveals two separate timedependent influences on body weight variance among strains. The QTL appeared at an early time point after infection, when virus replication has just begun and strong inflammatory host responses are not yet evident $[9,18,23]$. These observations indicate that the effect is most likely related to the experimental protocol, namely the stress to anesthesia and intra-nasal application as well as treatment recovery. Treatmentdependent QTLs were described previously [24]. It is worth to note that mock-infection of the parental DBA/2J and C57BL/6J mice did not lead to a lasting body weight loss over a longer time interval except for a slight drop in body weight on day 1 p.i. (Additional file 4: Figure S3).

We also performed a QTL analysis for the PC1 and PC2 described above. PC1 detects a significant QTL on chromosome 5 (LRS: 19, effect size: 30\%, Figure 4A) as well as suggestive QTL peaks on proximal chromosome 16 and on chromosome 17 (Figure 4A). Thus, the PC1 confirmed the significant QTL on chromosome 5 found with the daily body weight loss traits. Interval mapping of PC2 detected no significant QTL and one suggestive QTL on chromosome 13 (Figure 4B) which was not seen in any other trait.

\section{Survival rate and mean time to death traits confirmed the QTL on chromosome 5 and detected another significant QTL on chromosome 19}

The analysis of survival rate traits on days 7,8 and 11 p.i. revealed significant peaks on chromosomes 5 and 19 and suggestive peaks on chromosomes 1, 2, 3, 10, 16 and 17 (Figure 5A-C). The effects of these QTLs were again time-dependent. Qivr5 was significant at day 7 (LRS: 24.8, effect size: $37 \%$ ) and day 8 p.i. (LRS: 19.7, effect size: $31 \%$ Figure 5A, B) and its effect was still evident from day 9 until 11 p.i. (Additional file 5: Figure S4 and Figure 5C). Similarly, another significant QTL with time-dependent effects was observed on chromosome 19 (Qivr19) at day 8 (LRS: 19.4; effect size: 29\%) that could also be detected at day 7 and days 9-11 (Figure 5A-C and Additional file 5: Figure S4). Qivr5 and Qivr19 resulted from a positive influence of $\mathrm{DBA} / 2 \mathrm{~J}$ on survival, whereas Qivr16 (distal locus) and Qivr17-2 resulted from a positive influence of $\mathrm{C} 57 \mathrm{BL} / 6 \mathrm{~J}$ alleles to increase survival. Furthermore, MTTD analysis confirmed Qivr5 as a significant QTL (LRS: 20.5, effect size: 32\%), and Qivr19 was almost significant for this trait (Figure 5D). In addition, suggestive QTLs were found on chromosomes 2 and 17 for the MTTD trait.

In conclusion, survival and MTTD traits confirmed the significant QTL on chromosome 5, revealed an additional significant QTL on chromosome 19 and several suggestive QTLs. All QTLs showed a time-dependent effect.

\section{Composite interval and pair-scan mapping indicates various interactions of QTLs}

The strongest QTLs map to chromosomes 5 and 19. We therefore performed composite interval mapping in which the contributions of these strong QTLs were factored out to reveal possible secondary QTLs. When we controlled for Qivr19, the linkage to distal chromosome 16 increased and became nearly significant for both survival at day 8 and MTTD (Figure 6A, B). The linkage to chromosome 2 increased slightly. However, control for the contribution of Qivr5 did not reveal any additional loci linked to survival or MTTD traits (Figure 6C, D). 


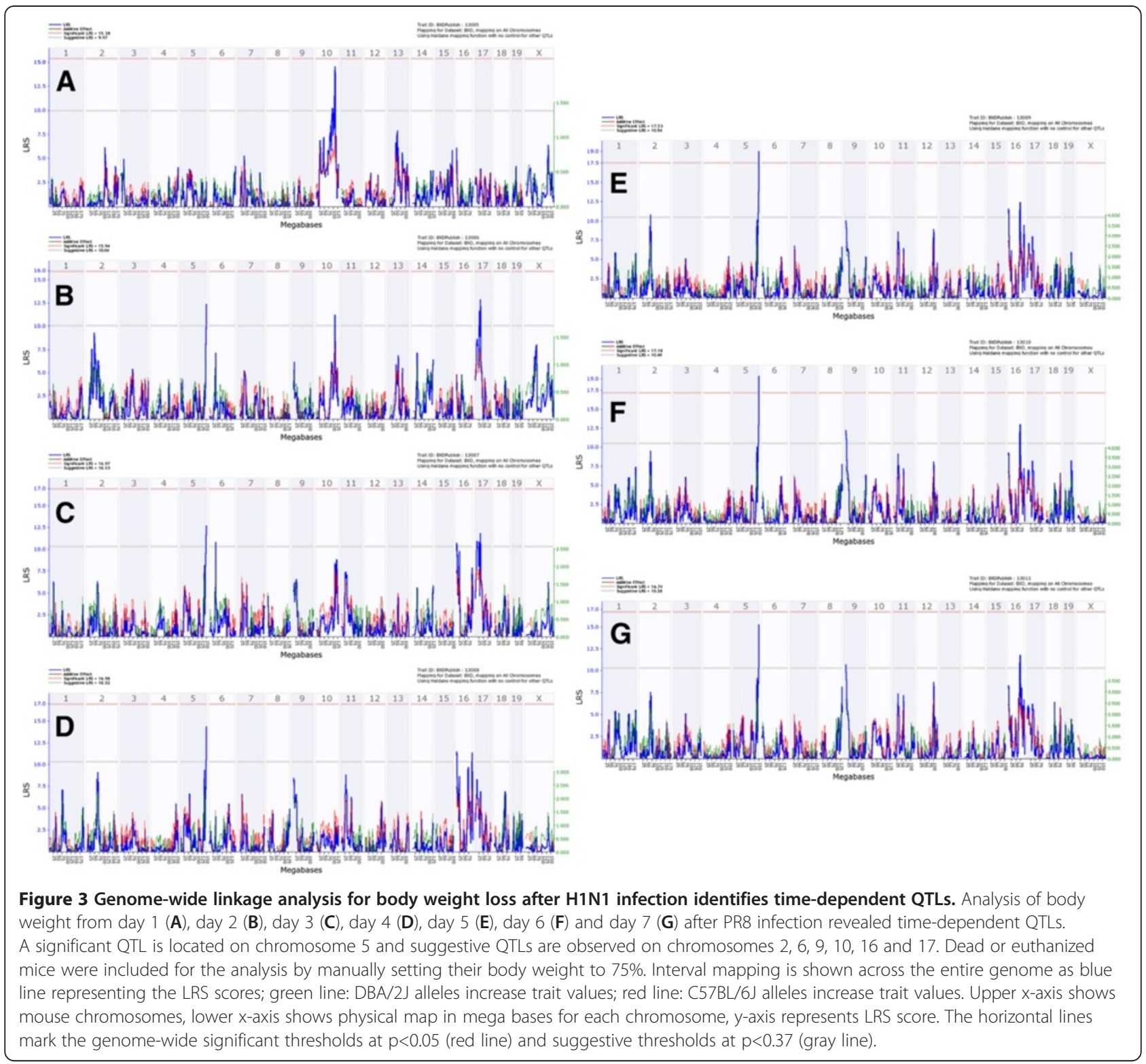

Finally, we analyzed the joint additive effects of QTLs described above as well as possible epistatic interactions among these QTLs. When using a full two-locus model (Trait Variance $=\mathrm{Q} 1+\mathrm{Q} 2+\mathrm{Q} 1 \times \mathrm{Q} 2$ ), we found two potential interactions between Qivr5 and a new locus on chromosome 9 as well as between Qivr5 and Qivr19, respectively, for the survival trait at day 8 (Figure 7A). The inclusion of an interaction term increases the LRS by 23 (Additional file 6: Figure S5). For both Qivr5 chromosome 9 interaction (Figure 7B) and Qivr5 Qivr19 interaction (Figure 7C), the allele combination DBA/2J / DBA/2J showed highest and the combination C57BL/6J / C57BL/6J lowest survival scores. All differences were highly significant.
Analysis of QTL regions identified several candidate genes that may contribute to host susceptibility or resistance

In total, the mapping studies revealed five QTLs on chromosomes 2, 5, distal 16, 17 and 19 (Qivr2-2, Qivr5, Qivr16, Qivr17-2 and Qivr19) that did merit further analysis because they were consistently observed in at least two traits and exerted an effect on at least two different days p.i.

For the candidate gene searches, we defined the critical regions of the QTLs manually by considering peak height, its shoulder and bootstraps as guidance (Figure 8). We then investigated these Qivr intervals for potential candidate genes that may be causal for the studied traits 


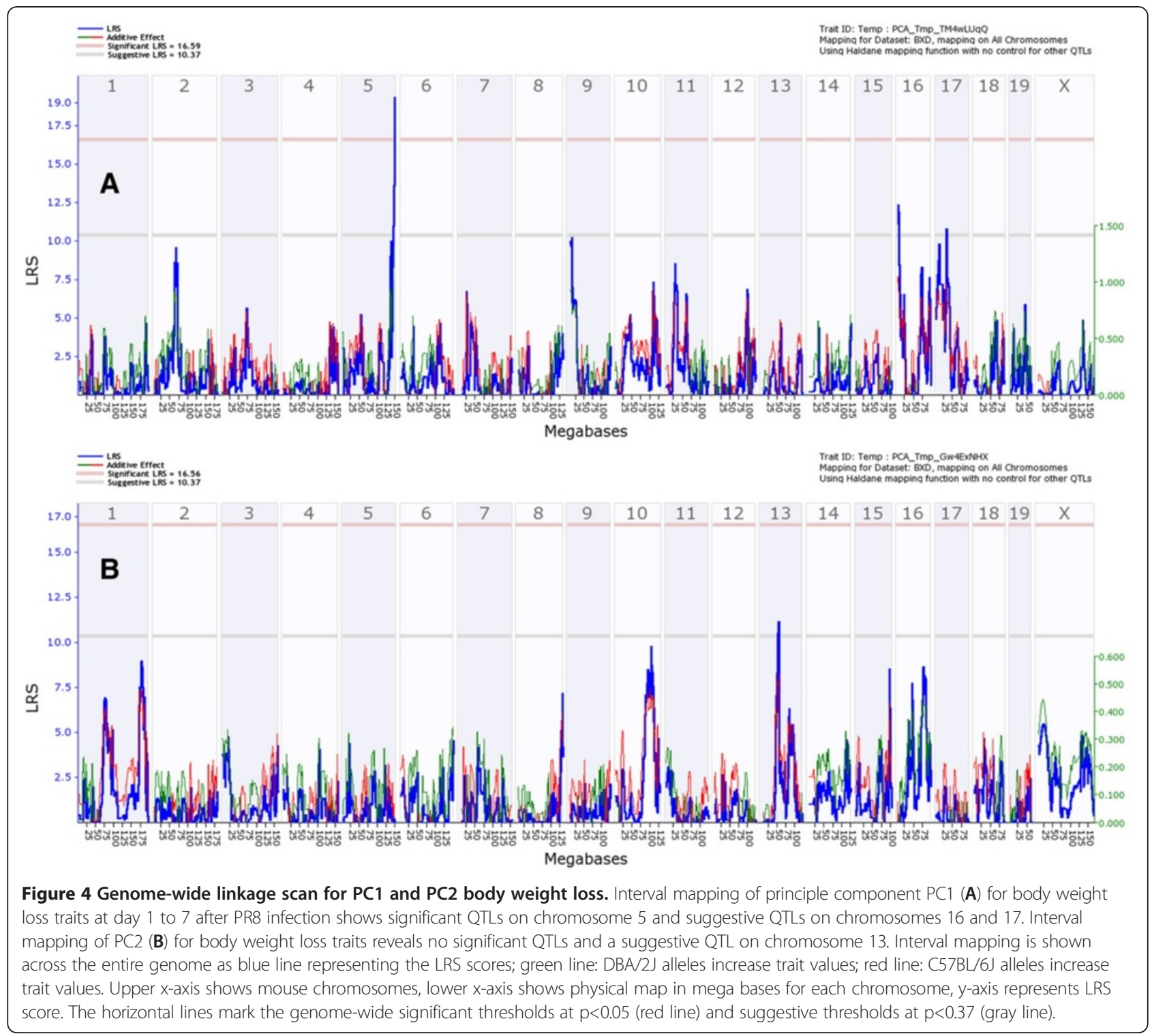

(Additional file 7: Figure S6). We first used the QTLminer tool in GeneNetwork [25] to identify all genes in the QTL intervals and to obtain associated GO terms. Next, we select all annotated genes within the QTL intervals that were expressed between day 1 and day 60 after infection of C57BL/6J mice with PR8M virus (the latter data set is derived from a separate study (Pommerenke et al., PLoS $\mathrm{ONE}$, in press). Subsequently, these genes were further characterized for the following attributes: genes that were up- or up-regulated in infected lungs by at least 1.5-fold in C57BL/6J after PR8M infection, genes carrying an insertion or deletion or a non-synonymous nucleotide change in the open reading frame, genes exhibiting a cisexpression QTL in the lung [26], and genes that were differentially expressed by at least 1.5-fold in C57BL/6J and DBA/2J mice in infected lungs between day 1 and day 8 p.i. [23] and Pommerenke et al., PLoS ONE, in press). The strategy of the QTL mining is shown as flow chart in the Additional file 7: Figure S6, and the final results are presented in Table 1. Furthermore, the attributes of all genes located in the QTL regions are listed in detail in the Additional file 8: Table S2). Using these combined attributes, we identified 31 genes as the most likely candidates to regulate the traits controlled by Qivr2-2, Qivr5, Qivr16, Qivr17-2 and Qivr19 (listed in Table 2). These genes were further evaluated based on their known function from the literature and phenotypes in knock-out mouse mutants (see discussion).

\section{Discussion}

$\mathrm{DBA} / 2 \mathrm{~J}$ and $\mathrm{C} 57 \mathrm{BL} / 6 \mathrm{~J}$ mice have been shown previously to differ largely in their susceptibility to H1N1 

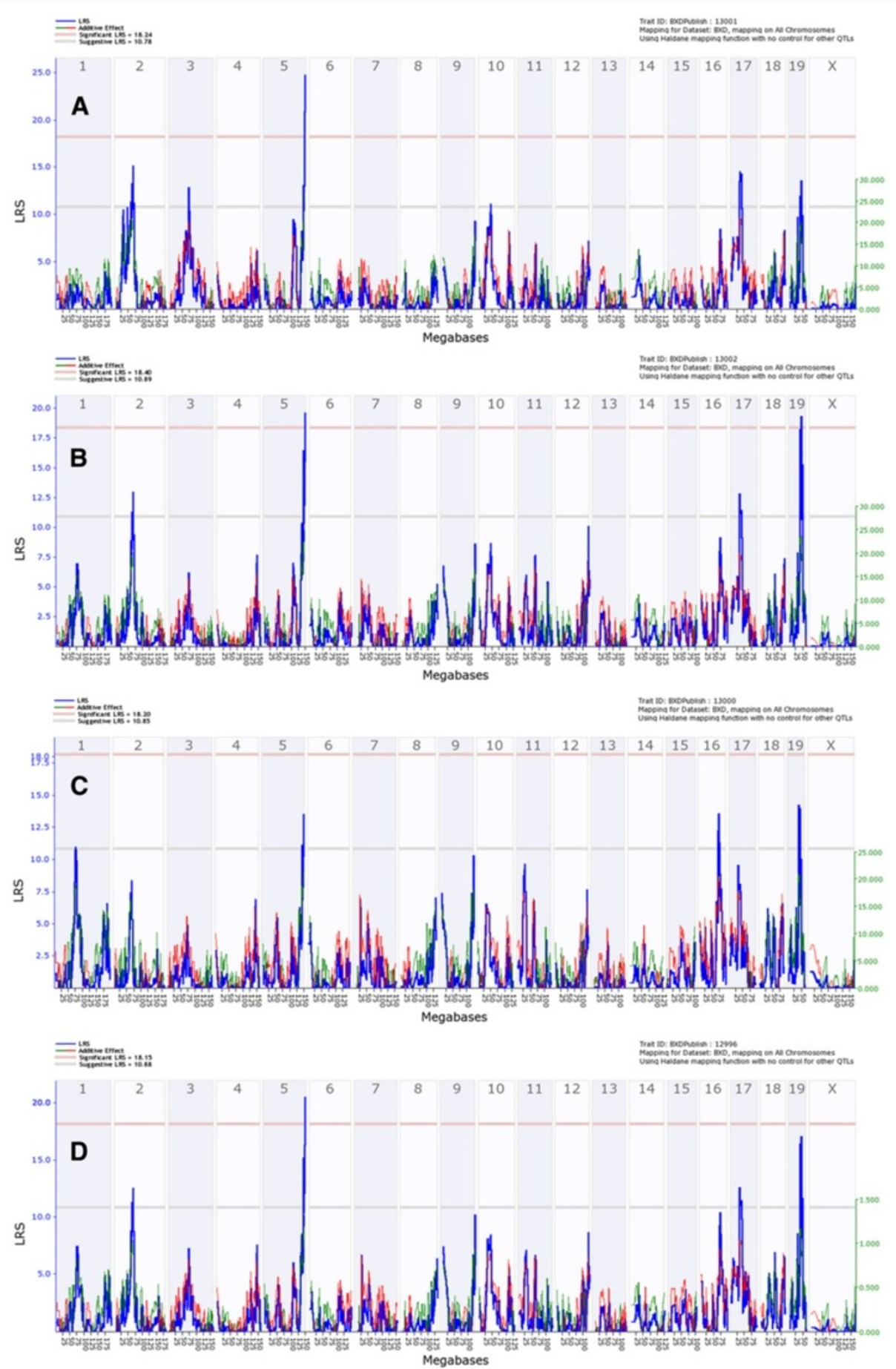

Figure 5 Genome-wide linkage scan for survival rate and mean time to death confirms QTLs on chromosomes 5 and 19. Interval mapping of survival rates (in \%) after PR8 infection at day 7 (A), day 8 (B) and day 11 (C) show significant QTLs on chromosomes 5 and 19. Suggestive QTLs are observed on chromosomes 2, 3, 10,16 and 17. Interval mapping using mean time to death confirmed the significant QTL on chromosome 5 and revealed suggestive QTLs on chromosomes 2, 17 and 19 (D). Interval mapping is shown across the entire genome as blue line representing the LRS scores; green line: DBA/2J alleles increase trait values; red line: C57BL/6J alleles increase trait values. Upper $x$-axis shows mouse chromosomes, lower $x$-axis shows physical map in mega bases for each chromosome, $y$-axis represents LRS score. The horizontal lines mark the genome-wide significant thresholds at $p<0.05$ (red line) and suggestive thresholds at $p<0.37$ (gray line). 


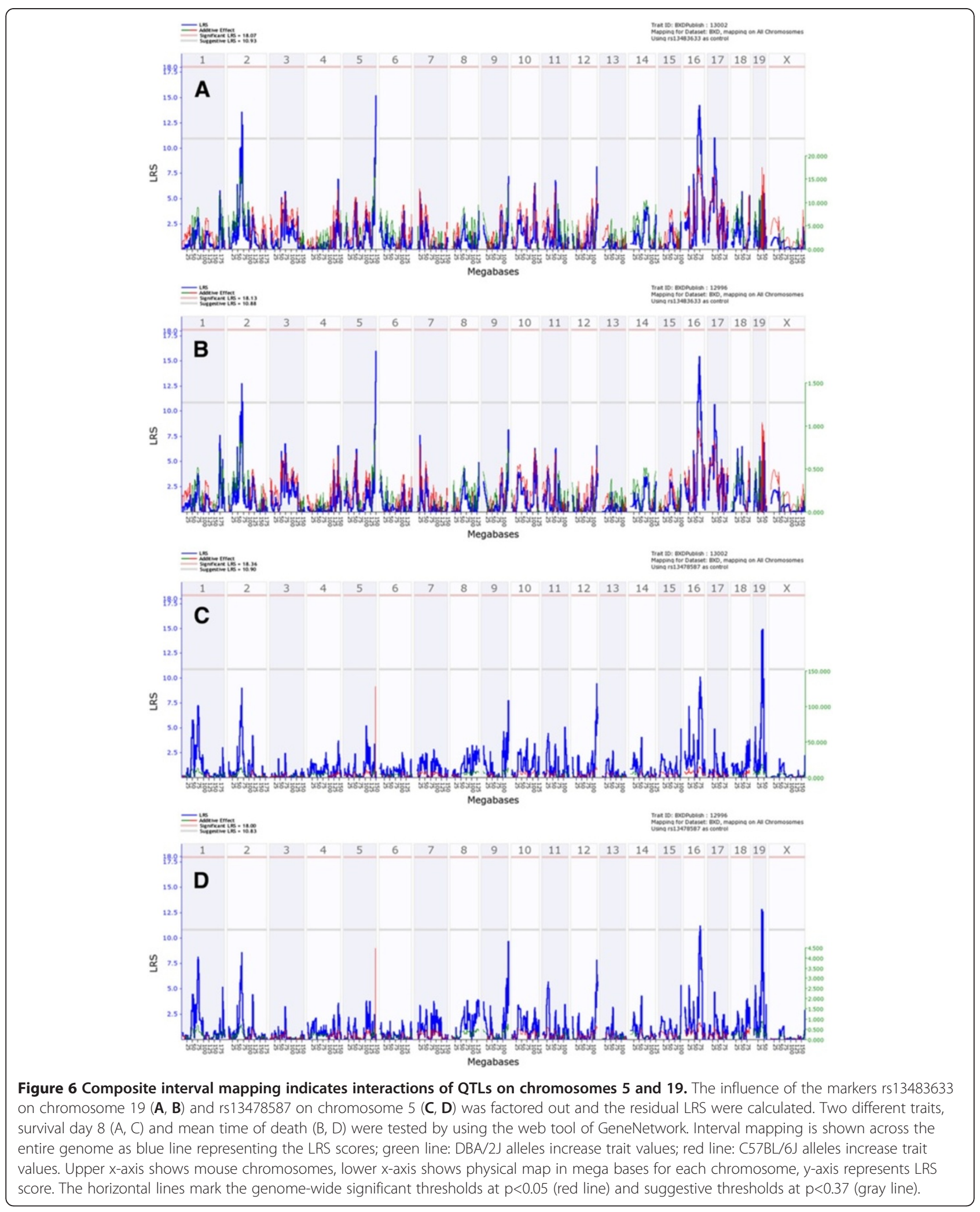




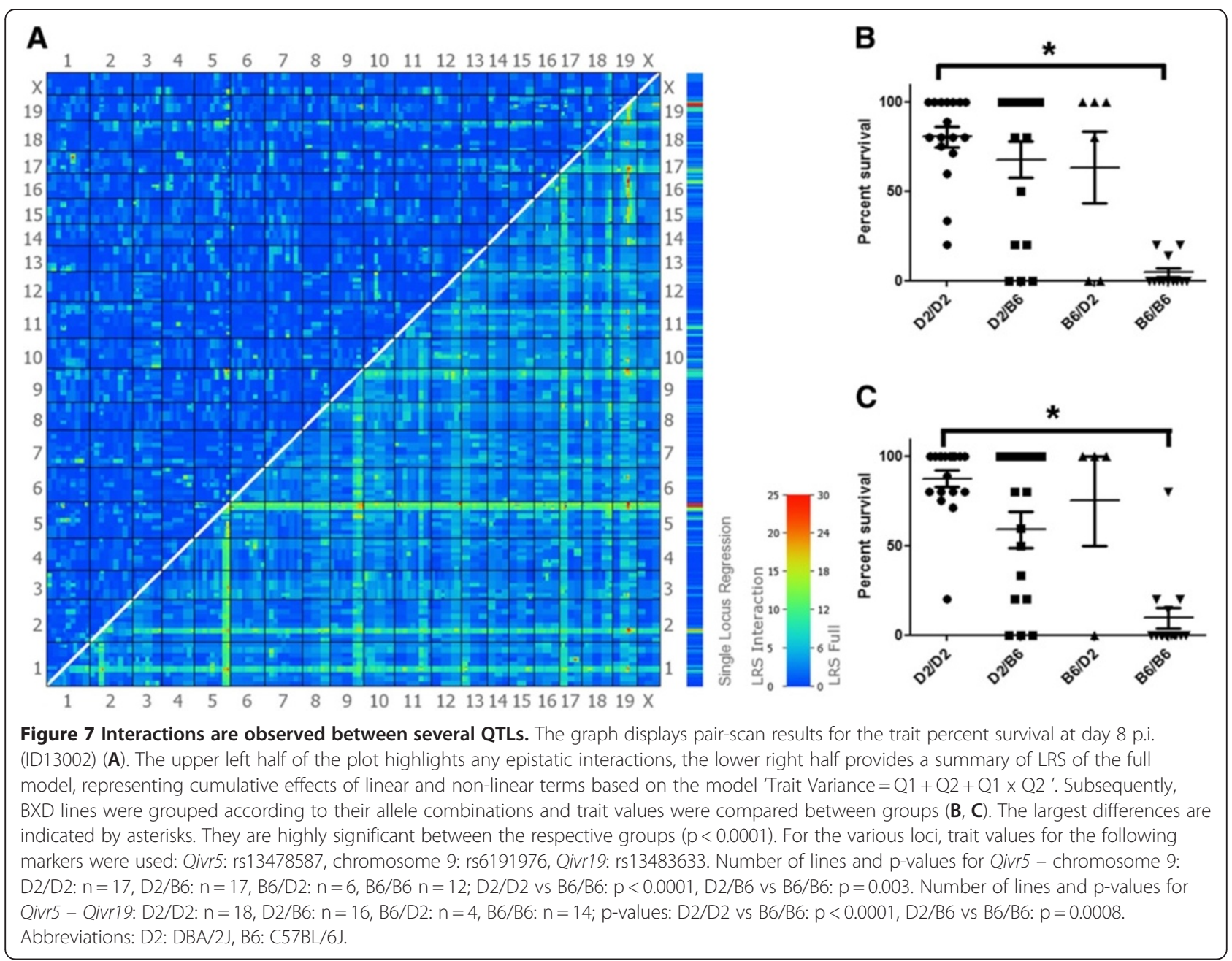

(PR8M) influenza A virus [9,18]. Here, we expanded these studies and utilized the BXD recombinant inbred set of mouse strains to map the genomic regions that are responsible for differences in these two mouse strains. We monitored three phenotypic traits, body weight over time, survival over time and mean time to death to identify quantitative trait for influenza resistance. Two significant QTLs, Qivr5 and Qivr19, were found on chromosomes 5 and 19, respectively. Furthermore several suggestive QTLs, Qivr2-2, Qivr16 and Qivr17-2 were observed in at least two traits and at two days on chromosomes 2, 16 and 17, respectively. Composite mapping revealed an additional almost significant QTL at distal chromosome 16, Qivr16.

A similar analysis for host resistance to influenza has been performed previously after infecting 66 BXD strains with $\mathrm{H} 5 \mathrm{~N} 1$ influenza virus. This study reported three significant QTLs on chromosomes 2, 7, and 17 [12]. Thus, none of these significant QTLs overlaps with the QTLs identified in our analysis. Five of the strains that were resistant (all infected mice survived) in our study were also resistant in the study of [12] where a total of 14 strains were found to be resistant. Five strains that were highly susceptible in our study $(100 \%$ of infected mice died) were also highly susceptible in the study by [12] of a total of 26 susceptible strains. Furthermore, five strains that were resistant in our study were susceptible in the study by [12]. Thus, there is also not much overlap between the two studies with respect of susceptible and resistant strains. The differences between the two studies are most likely explained by the use of two different influenza virus subtypes. The H1N1 virus from our study represents a subtype with a monobasic hemagglutinin (HA) cleavage site, whereas the H5N1 which was used in the study by Boon et al. is a subtype with a polybasic HA cleavage site. The cellular tropism of these two subtypes for virus replication and processing is quite different, because monobasic viruses are dependent on cell-specific proteases for the processing of the HA whereas polybasic subtypes can be processed by more ubiquitously expressed host proteases, e.g. [27-32]. Therefore, the contribution of host 


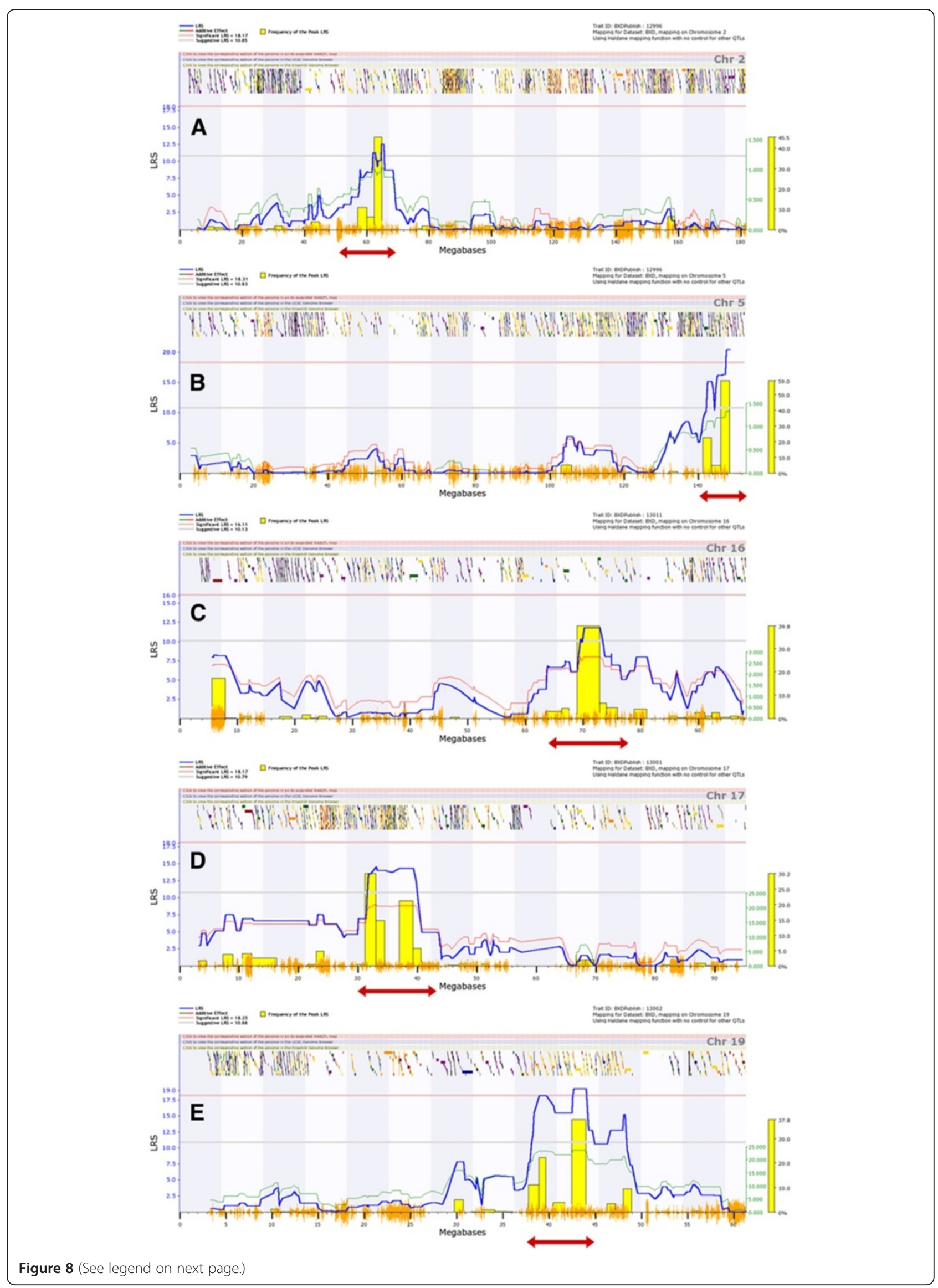


(See figure on previous page.)

Figure 8 Detailed maps of QTLs contributing to host susceptibility and resistance to PR8 influenza A infection. Interval mapping was performed for chromosomes 2 (A), 5 (B), 16 (C), 17 (D) and 19 (E). The critical intervals were selected based on the peak shapes and the bootstrap signals: Qivr2-1 (56-68 Mb), Qivr5 (140-153 Mb), Qivr16 (64-78 Mb), Qivr17-2 (30-44 Mb) and Qivr19 (37-45 Mb). The Qivr intervals are delineated by red arrows. The yellow bars represent the frequencies of peak LRS using bootstrap analysis. The multicolored chatters along the top of the graph are hyperlinks to sites with additional genetic and sequence information. The orange chatter along the $x$-axis indicates the density of SNPs present in the BXD strains. Interval mapping is shown across the entire genome as blue line representing the LRS scores; green line: DBA/2J alleles increase trait values; red line: C57BL/6J alleles increase trait values. Upper $x$-axis shows mouse chromosomes, lower $x$-axis shows physical map in mega bases for each chromosome, $y$-axis represents LRS score. The horizontal lines mark the genome-wide significant thresholds at $p<0.05$ (red line) and suggestive thresholds at $p<0.37$ (gray line).

factors to susceptibility may be different between $\mathrm{H} 1$ and $\mathrm{H} 5$ containing virus subtypes.

Another study described the genetic mapping of susceptibility and resistance factors after infecting a panel of $29 \mathrm{AxB} / \mathrm{BxA}$ congenic strains with a mouse-adapted $\mathrm{H} 3 \mathrm{~N} 2$ influenza virus [33]. The $\mathrm{AxB} / \mathrm{BxA}$ congenic strains were generated from a cross of susceptible $A / J$ and resistant $\mathrm{C} 57 \mathrm{BL} / 6 \mathrm{~J}$ parental mouse strains. The authors found three major QTLs on chromosomes 2, 6 and 17. The QTL on chromosome 17 overlaps with the Qivr17-2 locus which we found in our study. Furthermore, the candidate gene Pla2g7 that was identified in their study was also detected as candidate gene in our analysis (see below).

The influence of genetic factors determining the host response to $\mathrm{H} 1 \mathrm{~N} 1$ influenza virus infections was also examined in mice of the pre-Collaborative Cross collection [34]. In this study, gene expression levels in extreme responders were used to identify expression QTLs (eQTL). One gene that exhibited a cis-eQTL, Sik1 (salt inducible kinase 1), was located in the Qivr17-2 interval from our study, and we also identified it as potential quantitative trait gene (Table 2). This gene is associated with the GO terms 'negative regulation of transcription from RNA polymerase II promoter, regulation of cell differentiation, and protein kinase cascade'. However, no specific infection-related functions have been yet described for this gene.

One of the most interesting findings in our study was the time-dependent effect of QTLs which we observed in the body weight and survival traits. The peak QTLs for the two significant QTLs, Qivr5 and Qivr19, were found at different times p.i., day 6 and day 8, respectively. In addition, the effects of both QTLs were not only evident at the times p.i. where they exerted the significant peak QTL signals but also several days before and after the peak. Furthermore, for the suggestive QTLs, also time-dependent effects were observed. These results suggest that the causal genes underlying different QTLs act at different time points of the host defense.

Most interestingly, Qivr5 as well as Qivr19 represent a positive influence on body weight, survival and MTTD from the DBA/2J haplotype, the susceptible strain.
These findings indicate that genomic regions from the susceptible parent are able to increase resistance when combined with the resistant parental genome. We are now analyzing several BXD strains that were more resistant than the parental $\mathrm{C} 57 \mathrm{BL} / 6 \mathrm{~J}$ mice in more detail. One possible mechanism to explain such an effect may be that an activator (secreted ligand or transcription factor) is expressed in susceptible DBA/2J mice but the corresponding target (receptor or regulated gene) is mutated. On the other hand, in C57BL/6J mice, the target but not the activator may be mutated. If the wild type alleles are now coming together in a BXD strain, the functional activator finds its functional target and thereby an increased resistance state is achieved.

Both composite and interaction mapping revealed many genetic interactions between $\mathrm{C} 57 \mathrm{BL} / 6 \mathrm{~J}$ and DBA/2 J alleles. Thus, many genomic regions from the parental strains are able to contribute to the host response and this effect depends strongly on the allele combinations in the respective QTLs. These observations may be studied further in double congenic mouse lines.

We subsequently analyzed the five QTL intervals, Qivr2-2, Qivr5, Qivr16, Qivr17-2 and Qivr19 in more detail to identify genes that may be causal for resistance or susceptibility. In total, 830 genes are located in these intervals. We narrowed down the total number of genes to 31 candidates (Table 2) by using additional information, such as temporal expression after PRM8 infection (Pommerenke et al., PLoS ONE, in press), cis-eQTLs in non-infected lungs [26], differences in expression between DBA/2J and C57BL/6J [23], and sequence variants in the coding regions.

Qivr5 contains the candidate gene Eif2ak1 (eukaryotic translation initiation factor 2 alpha kinase 1) that is a member of eIF2alpha kinases which have been associated with anti-viral host responses [35]. Boon et al. described another eIF2alpha kinase, Eif2ak2 / Pkr (eukaryotic translation initiation factor 2-alpha kinase 2), in the Qirv17 locus after infection with influenza H5N1 [12]. Eif2ak2 plays a critical role in modulating immunoglobulin expression during RSV infection. In addition Eif2ak2 knockout mouse mutants are more susceptible to influenza infections [36,37]. We have initiated the generation of a 
Table 1 Candidate genes in mapped QTL intervals

\begin{tabular}{|c|c|c|c|c|c|c|c|c|}
\hline \multirow[t]{2}{*}{ Qivr } & \multirow[t]{2}{*}{ Interval } & \multirow[t]{2}{*}{$\begin{array}{c}\text { Allele } \\
\text { increasing } \\
\text { survival }\end{array}$} & \multirow{2}{*}{$\begin{array}{l}\text { No of } \\
\text { genes in } \\
\text { interval }\end{array}$} & $\begin{array}{c}\text { No of genes } \\
\text { expressed } \\
\text { during infection }\end{array}$ & \multirow{2}{*}{$\begin{array}{c}\text { No of genes } \\
\text { with Indels } \\
\text { (FS in coding region) }\end{array}$} & \multirow[t]{2}{*}{$\begin{array}{l}\text { No of genes with } \\
\text { SNPs (non-synonymous } \\
\text { codons / stop codons) }\end{array}$} & \multirow[t]{2}{*}{$\begin{array}{c}\text { Cis-eQTLs in } \\
\text { non-infected lung }\end{array}$} & \multirow[t]{2}{*}{$\begin{array}{l}\text { Differentially } \\
\text { expressed } \\
\text { btw B6/D2 }\end{array}$} \\
\hline & & & & (up-/down- regulated) & & & & \\
\hline $2-2$ & $56-68 \mathrm{Mb}$ & D2 & 72 & $24(19)$ & - & $4 / 0$ & 6 & 3 \\
\hline 5 & 140-153 Mb & D2 & 179 & $83(57)$ & - & $9 / 0$ & 13 & 10 \\
\hline 16 & 64-78 Mb & B6 & 52 & $12(7)$ & $1^{a}$ & $5 / 0$ & 4 & 4 \\
\hline $17-2$ & $30-44 \mathrm{Mb}$ & B6 & 370 & $158(104)$ & $1^{\mathrm{b}}$ & $58 / 4^{c-f}$ & 32 & 40 \\
\hline 19 & $37-45 \mathrm{Mb}$ & $\mathrm{D} 2$ & 161 & $51(30)$ & $1^{9}$ & $14 / 1^{\mathrm{h}}$ & 11 & 4 \\
\hline
\end{tabular}

Up- or down-regulated genes were defined as genes that exhibited at least a 1.5 difference change in expression levels in lungs of infected mice compared to the non-infected controls. Genes were defined as differentially expressed exhibiting at least a 1.5 difference in expression changes in infected lungs of $\mathrm{C} 57 \mathrm{BL} / 6 \mathrm{~J}$ and $\mathrm{DBA} / 2 \mathrm{~J}$. Genes with sequence variations: ${ }^{\mathrm{a}} \mathrm{Robo} 1,{ }^{\mathrm{b}} \mathrm{Lst} 1,{ }^{\mathrm{c}} \mathrm{Brd2},{ }^{\mathrm{d}} \mathrm{H} 2-\mathrm{Ab1} 1{ }^{\mathrm{e}} \mathrm{H} 2-\mathrm{Bl},{ }^{\mathrm{f}} \mathrm{Rpp} 21,{ }^{\mathrm{g}} \mathrm{Tctn} 3,{ }^{\mathrm{h}} \mathrm{Dhdpsl}$. Abbreviations: FS: frame shift in coding region, SNP: single nucleotide polymorphism, cis-eQTL: cis regulated expression QTL, B6: C57BL/6J, D2: DBA/2J.

congenic mouse lines for the chromosome 5 interval to verify and further characterize the effect of this region for resistance to influenza infection.

Qivr2-2 contains two candidate genes, Itgb6 (integrin beta 6) and Ifih1 (interferon induced with helicase $\mathrm{C}$ domain 1), with known functions in the host defense to viral infections. Itgb6 mouse knock-out mutants exhibit severe pneumonia and an increase in granulocyte recruitment to the lung [38]. The protease-activated receptor 1-mediated enhancement of Itgb6-dependent TGF-beta activation has been proposed to represent one mechanism by which activation of the coagulation cascade contributes to the development of acute lung injury [39]. The Ifih1 gene is also known as MDA5 (Melanoma Differentiation-Associated protein 5). IFIH1 is part of the RIG-I-like receptor (RLR) family, which function as pattern recognition receptors and are activated upon binding of virus dsRNA [40]. IFIH1 functions as cytosolic receptor that leads to the selective activation of type I IFN genes and is indispensable for sustained expression of IFN in response to paramyxovirus infection [41,42]. Ifih1 mutant knock-out mice exhibit an impaired response to different viral pathogens $[43,44]$.

Qivr16 contains two potential genes with known functions in the host defense and lung function, Robol (roundabout homolog 1 (Drosophila)) and Nrip1 (nuclear receptor interacting protein 1). DBA/2J mice carry a frame shift mutation in the Robol gene which might lead to an impaired function of the encoded protein. Robol has been described to be involved in guidance and migration of axons, myoblasts, and leukocytes in vertebrates (e.g. [45-47]) but is also expressed in the developing lung [48]. Robo1 knockout mutants exhibit a delayed lung maturation and bronchial hyperplasia. The latter results suggest that Robo1 may be involved in maintaining proper lung function and it may become essential when lung epithelium is destroyed during an influenza infection. Nrip1/Rip140 functions as a co-activator for cytokine gene promoter activity via direct protein-protein interactions with the
NFkappaB subunit RelA and histone acetylase cAMPresponsive element binding protein (CREB)-binding protein (CBP) [49]. It is involved in modulating proinflammatory responses in macrophages [50].

Qivr17-2 represents a positive influence of the C57BL/6 J genotype on body weight, survival and MTTD. This QTL is located in a gene-rich region which carries many genes that are involved in the host immune response, in particular the $H 2$ histocompatibility genes which are involved in antigen presentation [51]. Therefore, many candidate genes are found in the Qivr17-2 region. The Lst1 (leukocyte specific transcript 1) gene is of special interest because the DBA/2J allele mice carries a single nucleotide deletion in the first exon resulting in a frame shift of the open reading frame. This mutation most likely results in a non-functional Lst1 protein in DBA/2 J mice. We confirmed the presence of the deletion by sequencing the parental DBA/2J and some BXD strains carrying the $\mathrm{DBA} / 2 \mathrm{~J}$ allele. The wild type allele was confirmed in C57BL/6J mice and in some BXD strains carrying the C57BL/6J allele. In humans, LST1 plays a role in the regulation of the immune response to inflammatory diseases such as rheumatoid arthritis, microbial infection or Rubella vaccine-induced immunity [52-55]. Also, Lst1 is up-regulated after influenza A infection in C57BL/6J mice starting at day 2 and exhibits a strong peak of expression at day 8 p.i. Pommerenke et al., 2012 (Pommerenke, C., E. Wilk, B. Srivastava, A. Schulze, N. Novoselova, R. Geffers, and K. Schughart. 2012. Global transcriptome analysis in influenza-infected mouse lungs reveals the kinetics of innate and adaptive host immune responses. PLoS ONE. 7:e41169.). Thus, the expression profile and known functions of Lst1 fit well with a possible critical role for the host defense to influenza A virus. We initiated the generation of knockout mice to evaluate the role of Lst1 in more detail. In addition, a second, most interesting candidate, Pla2g7 (phospholipase A2, group VII (platelet-activating factor acetylhydrolase, plasma)) was identified in the Qivr17-2 interval. In 
Table 2 GO-terms and functions observed in knock-out mice of 31 potential candidates from QTL intervals

\begin{tabular}{|c|c|c|c|c|c|}
\hline Qivr & $\begin{array}{l}\text { Gene } \\
\text { symbol }\end{array}$ & Gene description & Function & KO phenotype & $\begin{array}{l}\text { Type } \\
\text { polymorphism } \\
\text { in ORF }\end{array}$ \\
\hline Qivr2-2 & $\operatorname{ltg} 66$ & integrin beta 6 & $\begin{array}{l}\text { Integrin-mediated signaling } \\
\text { pathway, inflammatory response, } \\
\text { cell-matrix adhesion }\end{array}$ & $\begin{array}{l}\text { Baldness associated with } \\
\text { macrophage infiltration of skin, } \\
\text { exaggerated pulmonary } \\
\text { inflammation, impaired mucosal } \\
\text { mast cell response to nematode } \\
\text { infection. }\end{array}$ & ns (1) \\
\hline Qivr2-2 & Ifih1 & $\begin{array}{l}\text { interferon induced with } \\
\text { helicase } C \text { domain } 1\end{array}$ & $\begin{array}{l}\text { Response to virus, innate } \\
\text { immune response, regulation } \\
\text { of apoptosis, RIG-I-like receptor } \\
\text { signaling pathway }\end{array}$ & $\begin{array}{l}\text { Increased virus-associated morbidity } \\
\text { and mortality, decreased cytokine } \\
\text { response to several viral infection. }\end{array}$ & ns (5) \\
\hline Qivr5 & Eif3b & $\begin{array}{l}\text { eukaryotic translation } \\
\text { initiation factor 3, } \\
\text { subunit B }\end{array}$ & Translation, translation initiation & NA & ns (1) \\
\hline Qivr5 & $S d k 1$ & $\begin{array}{l}\text { sidekick homolog } 1 \\
\text { (chicken) }\end{array}$ & Cell adhesion & NA & ns (1) \\
\hline Qivr5 & Eif2akl & $\begin{array}{l}\text { eukaryotic translation } \\
\text { initiation factor } 2 \text { alpha } \\
\text { kinase } 1\end{array}$ & $\begin{array}{l}\text { Negative regulation of translation, } \\
\text { response to stress, negative } \\
\text { regulation of cell proliferation, } \\
\text { regulation of elF2 alpha } \\
\text { phosphorylation by heme }\end{array}$ & $\begin{array}{l}\text { Enlarged heart size, abnormal } \\
\text { red blood cell development, } \\
\text { morphology, physiology with } \\
\text { macrocytic anemia. }\end{array}$ & ns (1) \\
\hline Qivr5 & Rnf6 & $\begin{array}{l}\text { ring finger protein } \\
\text { (C3H2C3 type) } 6\end{array}$ & $\begin{array}{l}\text { Ubiquitin-dependent protein } \\
\text { catabolic process, positive } \\
\text { regulation of transcription, } \\
\text { DNA-dependent }\end{array}$ & NA & ns (2) \\
\hline Qivr16 & Robol & $\begin{array}{l}\text { roundabout homolog } 1 \\
\text { (Drosophila) }\end{array}$ & $\begin{array}{l}\text { Cell differentiation, axon guidance, } \\
\text { chemotaxis }\end{array}$ & $\begin{array}{l}\text { Neonatal death, aphagia, delayed } \\
\text { lung maturation and bronchial } \\
\text { hyperplasia. }\end{array}$ & insertion \\
\hline Qivr16 & Nrip1 & $\begin{array}{l}\text { Nuclear receptor } \\
\text { interaacting protein } 1\end{array}$ & Regulation of transcription & $\begin{array}{l}\text { Female infertility due to ovulation } \\
\text { failure. Male and female mice are } \\
\text { smaller than wild-type littermates. }\end{array}$ & ns (1) \\
\hline Qivr16 & Usp25 & $\begin{array}{l}\text { ubiquitin specific } \\
\text { peptidase } 25\end{array}$ & $\begin{array}{l}\text { Ubiquitin-dependent protein } \\
\text { catabolic process }\end{array}$ & NA & ns ( 1$)$ \\
\hline Qivr17-1 & Cryaa & crystallin, alpha A & $\begin{array}{l}\text { Negative regulation of apoptosis, } \\
\text { negative regulation of caspase } \\
\text { activity, lens fiber cell } \\
\text { morphogenesis }\end{array}$ & $\begin{array}{l}\text { Small lenses that develop } \\
\text { progressive opacity beginning } \\
\text { in the nucleus. }\end{array}$ & no \\
\hline Qivr17-2 & Snfilk/Sik1 & SNF1-like kinase & $\begin{array}{l}\text { Negative regulation of transcription } \\
\text { from RNA polymerase II promoter, } \\
\text { regulation of cell differentiation, } \\
\text { protein kinase cascade }\end{array}$ & NA & no \\
\hline Qivr17-2 & March2 & $\begin{array}{l}\text { membrane-associated } \\
\text { ring finger (C3HC4) } 2\end{array}$ & Endocytosis, biological process & NA & no \\
\hline Qivr17-2 & Tapbp & TAP binding protein & $\begin{array}{l}\text { Antigen processing and } \\
\text { presentation of exogenous peptide } \\
\text { antigen via MHC class I, } \\
\text { TAP-dependent; defense response }\end{array}$ & $\begin{array}{l}\text { Reduced and thermolabile MHC } \\
\text { class I surface expression due to } \\
\text { impaired peptide loading with } \\
\text { stabilizing peptides, impaired } \\
\text { T cell selection, altered NK } \\
\text { repertoire, lower CD8+ T cell } \\
\text { numbers, impaired responses to } \\
\text { select class I-restricted antigens. }\end{array}$ & ns (1) \\
\hline Qivr17-2 & $\mathrm{H} 2-\mathrm{Oa}$ & $\begin{array}{l}\text { histocompatibility } 2, \\
\text { O region alpha locus }\end{array}$ & $\begin{array}{l}\text { Antigen processing and presentation } \\
\text { of peptide or polysaccharide antigen } \\
\text { via MHC class II, regulation of T cell } \\
\text { differentiation, Graft-versus-host } \\
\text { disease, viral myocarditis }\end{array}$ & $\begin{array}{l}\text { Abnormal antigen presentation } \\
\text { via MHC class II, enhanced } \\
\text { selection of CD4+ single positive } \\
\text { thymocytes. Mice homozygous } \\
\text { for a different knock-out allele } \\
\text { show increased serum IgG1 levels. }\end{array}$ & ns (1) \\
\hline
\end{tabular}


Table 2 GO-terms and functions observed in knock-out mice of 31 potential candidates from QTL intervals (Continued)

\begin{tabular}{|c|c|c|c|c|c|}
\hline Qivr17-2 & $\mathrm{H} 2-\mathrm{DMa}$ & $\begin{array}{l}\text { histocompatibility 2, } \\
\text { class II, locus DMa }\end{array}$ & $\begin{array}{l}\text { Antigen processing and presentation } \\
\text { of exogenous peptide antigen via } \\
\text { MHC class II, positive regulation of } \\
\text { T cell differentiation, positive } \\
\text { regulation of immune response, } \\
\text { Graft-versus-host disease, viral } \\
\text { myocarditis }\end{array}$ & $\begin{array}{l}\text { Impaired antigen presenting cell } \\
\text { function, poor lgG responses to } \\
\text { T-dependent antigens, reduced } \\
\text { numbers of mature CD4+ T cells, } \\
\text { increased susceptibility to } \\
\text { Leishmania major infection. }\end{array}$ & ns (2) \\
\hline Qivr17-2 & Tap2 & $\begin{array}{l}\text { transporter 2, ATP-binding } \\
\text { cassette, sub-family B } \\
\text { (MDR/TAP) }\end{array}$ & $\begin{array}{l}\text { Antigen processing and presentation } \\
\text { of exogenous protein antigen via } \\
\text { MHC class Ib, TAP-dependent; } \\
\text { positive regulation of T cell mediated } \\
\text { cytotoxicity, protection from natural } \\
\text { killer cell mediated cytotoxicity }\end{array}$ & $\begin{array}{l}\text { No CD8+ T cells, although } \\
\text { numbers of CD4+ T cells and } \\
\text { B cells are normal. }\end{array}$ & ns (6) \\
\hline Qivr17-2 & $\mathrm{H} 2-\mathrm{Ob}$ & $\begin{array}{l}\text { histocompatibility } 2, \\
0 \text { region beta locus }\end{array}$ & $\begin{array}{l}\text { Antigen processing and presentation } \\
\text { of peptide or polysaccharide antigen } \\
\text { via MHC class II, Graft-versus-host } \\
\text { disease, viral myocarditis }\end{array}$ & NA & ns (7) \\
\hline Qivr17-2 & $H 2-A b 1$ & $\begin{array}{l}\text { histocompatibility 2, } \\
\text { class II antigen A, beta } 1\end{array}$ & $\begin{array}{l}\text { Antigen processing and presentation } \\
\text { of peptide or polysaccharide antigen } \\
\text { via MHC class II, Graft-versus-host } \\
\text { disease, viral myocarditis }\end{array}$ & $\begin{array}{l}\text { Depletion of mature CD4+ T cells, } \\
\text { deficiency in cell-mediated } \\
\text { immune responses, increased } \\
\text { susceptibility to viral infections. }\end{array}$ & $\begin{array}{l}\text { ns (9) } \\
\text { stop_L }\end{array}$ \\
\hline Qivr17-2 & $\mathrm{H} 2-\mathrm{Aa}$ & $\begin{array}{l}\text { histocompatibility 2, } \\
\text { class II antigen A, alpha }\end{array}$ & $\begin{array}{l}\text { Antigen processing and presentation } \\
\text { of exogenous peptide antigen via } \\
\text { MHC class II, positive regulation of } \\
\text { T cell differentiation, Graft-versus-host } \\
\text { disease, viral myocarditis }\end{array}$ & $\begin{array}{l}\text { Lack of cell surface expression } \\
\text { of MHC class II molecules on } \\
\text { macrophages, decreased } \\
\text { CD4-positive T cell number, } \\
\text { increased CD8-positive } \\
\text { T cell number, thymus hyperplasia, } \\
\text { enlarged lymph nodes, altered } \\
\text { splenocyte response to } \\
\text { staphylococcal enterotoxin B. }\end{array}$ & ns (10) \\
\hline Qivr17-2 & Lst1 & $\begin{array}{l}\text { leukocyte specific } \\
\text { transcript } 1\end{array}$ & $\begin{array}{l}\text { Negative regulation of lymphocyte } \\
\text { proliferation, immune response, } \\
\text { cell morphogenesis }\end{array}$ & NA & $\begin{array}{l}\text { ns (1) } \\
\text { deletion }\end{array}$ \\
\hline Qivr17-2 & Gtf2h4 & $\begin{array}{l}\text { general transcription } \\
\text { factor } \| \mathrm{H} \text {, polypeptide } 4\end{array}$ & $\begin{array}{l}\text { Regulation of transcription, } \\
\text { DNA-dependent }\end{array}$ & NA & ns (3) \\
\hline Qivr17-2 & H2-T23 & $\begin{array}{l}\text { histocompatibility } 2, \\
\text { T region locus } 23\end{array}$ & $\begin{array}{l}\text { Antigen processing and presentation } \\
\text { of peptide antigen via MHC class I, } \\
\text { Graft-versus-host disease, viral } \\
\text { myocarditis }\end{array}$ & $\begin{array}{l}\text { CD4 }{ }^{+} T \text { cells have enhanced } \\
\text { responses after infection or } \\
\text { immunization, are resistant to } \\
\text { suppressor activity mediated by } \\
\text { a subset of CD8 }{ }^{+} \mathrm{T} \text { cells, but are } \\
\text { more susceptible to NK cell lysis. }\end{array}$ & ns (3) \\
\hline Qivr17-2 & $H 2-B l$ & $\begin{array}{l}\text { histocompatibility 2, } \\
\text { blastocyst }\end{array}$ & Antigen processing and presentation & NA & $\begin{array}{l}\text { ns (4) } \\
\text { stop_L }\end{array}$ \\
\hline Qivr17-2 & Rpp21 & $\begin{array}{l}\text { ribonuclease P } 21 \\
\text { subunit (human) }\end{array}$ & tRNA processing & NA & $\begin{array}{l}\text { ns (1) } \\
\text { stop_G }\end{array}$ \\
\hline Qivr17-2 & Trim26 & $\begin{array}{l}\text { tripartite motif } \\
\text { protein } 26\end{array}$ & Biological process & NA & ns (1) \\
\hline Qivr17-2 & Pla2g7 & $\begin{array}{l}\text { phospholipase A2, } \\
\text { group VII (platelet-activating } \\
\text { factor acetylhydrolase, } \\
\text { plasma) }\end{array}$ & $\begin{array}{l}\text { Inflammatory response, lipid catabolic } \\
\text { process }\end{array}$ & NA & ns (1) \\
\hline Qivr17-2 & Cyp39a1 & $\begin{array}{l}\text { cytochrome } \mathrm{P} 450, \\
\text { family } 39 \text {, subfamily a, } \\
\text { polypeptide } 1\end{array}$ & $\begin{array}{l}\text { Lipid metabolic process, oxidation } \\
\text { reduction }\end{array}$ & NA & ns (2) \\
\hline Qivr-19 & Sorbs1 & $\begin{array}{l}\text { sorbin and } \mathrm{SH} 3 \text { domain } \\
\text { containing } 1\end{array}$ & $\begin{array}{l}\text { Transport, focal adhesion assembly, } \\
\text { positive regulation of establishment } \\
\text { of protein localization in plasma } \\
\text { membrane }\end{array}$ & $\begin{array}{l}\text { Decreased triglyceride levels, } \\
\text { altered glucose homeostasis, } \\
\text { decreased white blood cells and } \\
\text { resistance to developing glucose } \\
\text { intolerance induced by a high } \\
\text { fat diet. }\end{array}$ & ns (6) \\
\hline Qivr-19 & Tctn3 & tectonic family member 3 & Apoptosis & NA & $\begin{array}{l}\text { ns ( } 1 \text { ) } \\
\text { insertion (2) }\end{array}$ \\
\hline
\end{tabular}


Table 2 GO-terms and functions observed in knock-out mice of 31 potential candidates from QTL intervals (Continued)

\begin{tabular}{lllll}
\hline Qivr-19 & Hps1 & $\begin{array}{l}\text { Hermansky-Pudlak } \\
\text { syndrome 1 homolog } \\
\text { (human) }\end{array}$ & $\begin{array}{l}\text { Positive regulation of natural killer } \\
\text { cell activation, secretion of lysosomal } \\
\text { enzymes }\end{array}$ & $\begin{array}{l}\text { Hypopigmentation and increased } \\
\text { bleeding time. Impaired natural } \\
\text { killer cell function, reduced } \\
\text { secretion of kidney lysosomal } \\
\text { enzymes, abnormal retinofugal } \\
\text { neuronal projections } \\
\text { characterize some alleles. }\end{array}$ \\
\hline Qivr-19 & Dnmbp & dynamin binding protein & $\begin{array}{l}\text { Intracellular signaling cascade, } \\
\text { regulation of Rho protein signal } \\
\text { transduction }\end{array}$ & NA \\
& & &
\end{tabular}

The genotype of C57BL/6J was used as reference for the sequence polymorphisms. The knockout mutant phenotype was identified in the MGI Mouse Genome Database. Gene Fign (fidgetin) fulfilled most criteria but was found to be expressed only at late times p.i. (after day 14) and was therefore omitted from the candidate gene list. Abbreviations: KO: knockout mutant, NA: not analyzed, SNP: single nucleotide polymorphism, ns: non-synonymous codons, ORF: open reading frame, stop_G: stop codon gained, stop_L: stop codon lost.

humans, increased activities of certain variants of PLA2G7 were associated with early coronary atherosclerosis and with endothelial dysfunction, but the gene may also exert an anti-inflammatory function [56-60]. The Pla2g7 gene was also identified as a potential candidate gene for susceptibility against infections with H3N2 influenza virus [33]. Pla2g7 expression levels in susceptible A/J mice were higher than in resistant $\mathrm{C} 57 \mathrm{BL} / 6 \mathrm{~J}$ mice after infection with H3N2 virus [33]. We also showed previously that Pla2g7 exhibits a cis-eQTL between C57BL/6J and DBA/2J in non-infected lungs where the DBA/2J allele shows high levels of expression [26]. Tnfrsf 21 which was identified by [33] as potential candidate of Qivr17-2 also exhibits a ciseQTL in non-infected BXD mice [26] but was not found to be regulated in C57BL/6 mice after infection (data not published). Tapbp (TAP binding protein) plays a major role in the antigen processing and MHC class I presentation by stabilizing the TAP peptide transporter, e.g. [61-65]. Also, Tap2 (transporter 2, ATP-binding cassette, sub-family B (MDR/TAP)) gene is involved in antigen processing and presentation $[63,66]$. Gtf $2 h 4$ (general transcription factor II $\mathrm{H}$, polypeptide 4) encodes a general transcription factor. Recruitment and activation of Gtf $2 h 4$ represents a ratelimiting step for the emergence of HIV from latency and sequence variants have been associated with multiple sclerosis [67-69].

Within the Qivr19 interval, only one gene, Hps1 (Hermansky-Pudlak syndrome 1 homolog (human)), has been associated with the host responses to infection. Mice carrying a natural mutation in the Hps1 gene showed an increased inflammatory response in alveolar macrophages after intranasal challenge with LPS [70].

The GeneNetwork database allows searching for other phenotypic traits that exhibit a genome-wide significant (LRS $\geq 18$ ) within the Qivr intervals identified by our study. Two phenotypic traits, related to neuronal responses (trait ID 11285) and body weight changes (trait ID 12838), are located to the Qivr16 locus. Also, the Qivr17-2 interval contained significant QTLs for other traits. Two traits are related to host infectious diseases, 'Ectromelia virus survival'
(ID 12672) and 'Chlamydia psittaci (6BC) infection response' (ID 11025) and four traits are associated with immune cell responses (ID 10201, 10466, 10238, 10236). In addition two traits described seizure responses (ID 10388, 10507), and one trait has not been disclosed yet (ID 13920). Within the early time chromosome 10 interval, three other traits exhibit their most significant QTLs: '3a,5a-THDOC in blood plasma 3 days after cycle 5 of chronic intermittent air vapor' (ID13027) and two non-disclosed traits. The first trait may relate to stress responses in the central nervous system (ID 13292 and 13846).

\section{Conclusions}

The mapping of resistance and susceptibility loci in the BXD population revealed several new QTLs and potential gene candidates that may be critical for the host defense against influenza A virus infection. Body weight and survival QTLs showed a time-dependent profile indicating that the genetic factors in these QTLs are important for the host response in a temporal dynamic fashion. Five QTL regions were examined in detail, and we identified several possible candidate genes that may be critical for the host response to influenza A infections in humans.

\section{Methods \\ Animals}

The mouse inbred strains C57BL/6J, DBA/2J and B6D2F1 were delivered from Janvier, France. Recombinant inbred mouse strains BXD were purchased from three different sources: The Jackson Laboratory, the University of Tennessee Health Science Center (Memphis, TN) and from Harlan, The Netherlands. For the analysis, mice were transferred to the animal facility in Braunschweig and adapted for at least two weeks to the new environment before starting experiments. Animals were maintained under specific pathogen free conditions. All experiments in mice were approved by an external committee and according to the national guidelines of the animal welfare law in Germany 
('Tierschutzgesetz in der Fassung der Bekanntmachung vom 18. Mai 2006 (BGBl. I S. 1206, 1313), das zuletzt durch Artikel 20 des Gesetzes vom 9. Dezember 2010 (BGBl. I S. 1934) geändert worden ist.'). The protocol used in these experiments has been reviewed by an ethics committee and approved by the 'Niedersächsisches Landesamt für Verbraucherschutz und Lebensmittelsicherheit, Oldenburg, Germany', according to the German animal welfare law (Permit Numbers: 33.42502/04-108/06, 33.9.42502-04-051/09).

\section{Virus and infection of mice}

The mouse-adapted influenza strain A/Puerto Rico/8/34 (H1N1; PR8M, [18] and references therein) was used for all infection studies. Stocks were prepared by infection of 10-day-old embryonated chicken eggs. After mice were anesthetized by intra-peritoneal injection of Ketamin-Xylazine solution in sterile $\mathrm{NaCl}(50 \mathrm{mg} / \mathrm{ml}$ Ketamine, Invesa Arzneimittel $\mathrm{GmbH}$, Freiburg; 2\% Xylazine, Bayer Health-Care, Leverkusen) with a dose adjusted to the individual body weight, mice were infected intranasally with $2 \times 10^{3}$ FFU of PR8M in $20 \mu \mathrm{l}$ of sterile phosphate-buffered saline. Mice were assayed daily for body weight (determined as \% of initial weight at day 0 ) and mortality during 13 days p.i. We used death as the end point for survival. Mice were sacrificed if body weight loss exceeded $25 \%$. It should be noted that for mice that did not show any signs of body weight loss over the entire time period after infection, we do not have additional parameters to verify that they have indeed been infected. However, these cases were very few. In addition, we have ample experience with this infection method and the failure rate, for example with the DBA/2J strain, is less that 5\%.

\section{Data handling and statistical analysis}

In total, $283 \mathrm{BXD}$ mice and 127 mice from the parental strains or F1 generation were used for the infection experiments. In total 53 BXD strains were infected with an average of 5 mice per strain. We performed all primary calculations using simple features and functions of Microsoft Excel. Three sets of analysis were performed for the following variables: (1) body weight in percentage from starting weight (day 0) using the strain medians to exclude outliers; (2) survival by calculating the survival rate of each strain from day 7 to 13 , (3) mean time to death in days. For statistical analyses, tests and visualization we used $R$, a free software environment for statistical computing and graphics (http://www.R-project.org). In order to test for batch effects or other co-factors, we visualized the data using multidimensional scaling based on the Sammon mapping method [71]. No clusters with respect to any of the cofactors age, weight at day 0 , experimenter, time of infection, or source of mice could be found in the visualizations.

\section{QTL mapping}

QTL mapping was performed using the web-based complex trait analysis available on the GeneNetwork website (www.genenetwork.org) and the mapping module to analyze phenotypes in context of mouse genotypic differences. Interval mapping evaluates potential QTLs at regular intervals and estimates the significance at each location with a graphical representation of the likelihood ratio statistics (LRS) using 2000 permutation tests $[19,22]$. LRS values may be converted to LOD scores by dividing by 4.61. For the two locus model the following equation was used: $\operatorname{Var}=Q 1+Q 2+Q 1 x Q 2+e$, where $V a r=$ the between-strain mean variance in the trait, $Q 1$ and Q2 are makers tightly linked to the loci, Q1XQ2 is the 'additive-by-additive' epistatic interaction term, and $e$ is the residual error. The original data sets can be obtained at www.genenetwork.org with the following identification numbers: body weight: 13005 to 13017; survival: 13000 to 13004 and mean time to death: 12996 . We performed full genome scans for epistatic interactions using the pair-scan module that is implemented in GeneNetwork. This module exploits the direct global optimization algorithm developed by [72]. The code compares the fit (as measured by LRS scores) for a purely additive model, a purely epistatic model, and the full model. The code also implements a permutation test $(n=500)$ and this enabled us to estimate the empirical $p$ value of the alternative models.

\section{Candidate gene discovery}

The QTL region analysis was initially performed using the QTLminer which has been implemented in GeneNetwork [25]. By using the automatic function of GeneNetwork we identified significant cis-QTLs with LRS higher than 18 at a genome-wide p-value of $<0.05$. Additionally the genes mapped within the analyzed QTLs were surveyed by the National Center for Biotechnology Information (NCBI) Entrez Gene website (http://www.ncbi.nlm.nih.gov/sites/entrez?db= gene) and the Jackson Laboratory's MGI Mouse Genome Database project (http://www.informatics. jax.org/) to identify potential candidate genes. The GeneRIF database (http://www.ncbi.nlm.nih.gov/projects/GeneRIF/GeneRIFhelp.html) was used as a primary source to search for known gene functions and corresponding citations.

All sequence variants between B6 and D2 parental genomes (SNPs, indels) were extracted by using a comparative analysis that relies on approximately $100 \mathrm{x}$ whole genome shot gun of DBA/2J [73]. All of these sequence data are available at http://ucscbrowser. genenetwork.org/, the GeneNetwork Variant Browser (http://www.genenetwork.org/webqtl/main.py?FormID= snpBrowser), and the NCBI Short Read Archive (18 files 
total, e.g., SRX037575, SRX013980, SRX013299, SRX012582, SRX012581, SRX012580); http://www.biomedcentral.com/ $1471-2105 / 11 / \mathrm{S} 4 / \mathrm{O} 7$.

\section{Additional files}

Additional file 1: Table S1. Body weight loss from day 1 until day 7 for all strains showing the mean values, SEM per day and number of mice per strain analyzed.

Additional file 2: Figure S1. Differential susceptibility to influenza A infection among different BXD strains, parental strains and F1 generation. Rank-ordered strain distribution pattern illustrating the percentage of surviving mice per strain after influenza A infection for 53 BXD, parental DBA/2J and C57BL/6J strains and F1 (B6D2F1) mice for day 7 (A, trait ID: 13001) and day 8 (B, trait ID: 13002). Rank-ordered strain distribution pattern showing mean time to death for $53 \mathrm{BXD}$, parental DBA/2J and C57BL/6J strains and F1 (B6D2F1) mice (C, trait ID: 12996).

Additional file 3: Figure S2. Principal component analysis of all body weight traits. Percent contribution of principal components to the total variance for body weight traits from day 1 until day 7 p.i. PC1 contributes about $80 \%$ and PC2 about $10 \%$ to the total variance.

Additional file 4: Figure S3. Body weight changes in mock-infected C57BL/6J and DBA/2J mice. Female DBA/2J $(n=4)$ and C57BL/6J $(n=3)$ mice were intranasally inoculated with $25 \mu \mathrm{l}$ PBS under anesthesia. Body weight changes for each group of treated mice at various days p.i. is shown with reference to the starting weight (\% body weight). Data represent mean values +/- SEM.

Additional file 5: Figure S4. Genome-wide linkage analysis for survival after H1N1 infection at days 9 and 10 p.i. Analysis of survival from day 9 (A) and day 10 (B) after PR8 infection revealed suggestive QTLs on chromosomes 5, 16, 17 and 19. Interval mapping is shown across the entire genome as blue line representing the LRS scores; green line: DBA/ 2J alleles increase trait values; red line: C57BL/6J alleles increase trait values. Upper $\mathrm{x}$-axis shows mouse chromosomes, lower $\mathrm{x}$-axis shows physical map in mega bases for each chromosome, $y$-axis represents LRS score. The horizontal lines mark the genome-wide significant thresholds at p0.05 (red line) and suggestive thresholds at p0.37 (gray line).

Additional file 6: Figure S5. Pair Scan analysis of trait 13002. The table provides the breakdown of trait 13002 as an example for a pair scan analysis study that compares the fit of the alternative models. An analysis of this type can be regenerated rapidly on any of the traits presented in our manuscript.

Additional file 7: Figure S6. Scheme to identify potential candidate genes in the analyzed QTL intervals. The detailed steps are described in the main manuscript.

Additional file 8: Table S2. List of genes in the QTL intervals that were studied in detail. The QTLminer tool in GeneNetwork was to identify all genes in the QTL intervals and to obtain associated GO terms and KEGG pathways. All annotated genes within the QTL intervals that were expressed between day 1 and day 60 after infection of C57BL/6J mice with PR8M virus were further analyzed for the following attributes: genes that were up- or down-regulated in infected lungs after PR8M infection, genes carrying an insertion or deletion or a non-synonymous nucleotide change in the open reading frame, genes exhibiting a cis-expression QTL in the lung, and genes that were differentially expressed in C57BL/6J and DBA/2J mice in infected lungs between day 1 and day 8 p.i. Abbreviations: FS: frame shift in coding region, SNP: single nucleotide polymorphism, cis-eQTL: cis-regulated expression QTL, B6: C57BL/6J, D2: DBA/2J, ns: non-synonymous codons, stop_G: stop codon gained, stop_L: stop codon lost, DEL: deletion, INS: insertion; ns (. . .): number of nonsynonymous codons. Legends: Expression d0-d60, $\log 2 \geq 8$ at any day during infection; No: $\log 2$ 8; ?: no expression data available. Regulation during infection (d0-d60): + - up or down regulation, genes that exhibited at least a 2-fold difference in changes of the expression levels in lungs of infected mice compared to non-infected controls; (+)(-): up-or down-regulation, genes that exhibited at least a 1.5-fold difference in changes of the expression levels in lungs of infected mice compared to the non-infected controls; no: no regulation. SNP: ns (..) number of non-synonymous codons; STOP_L: Stop codon lost, STOP_G: Stop codon gained; no: no SNPs between B6 and D2. Indel: DEL: Deletion; INS: Insertion; no: no INDEL. cisQTL: yes (. . .): LRS value has to be greater than $\geq 18$; no: no QTL or LRS 18. diff expressed (B6-D2) during infection: Genes were defined as differentially expressed (log2 $\geq 8$ ) at any day in infected lungs of C57BL/6J and DBA/2J; + -: Genes were defined as differentially expressed exhibiting at least a 2.0 difference in changes of the expression levels in infected lungs of C57BL/6J and DBA/2J; (+)(-) differentially expressed: Genes were defined as differentially expressed exhibiting at least a 1.5 difference in changes of the expression levels in infected lungs of C57BL/6J and DBA/2J; no: no regulation or not expressed; Score: the different attributes were counted.

\section{Competing interests}

The authors declare that they have no competing interests.

\section{Authors' contributions}

$\mathrm{TN}, \mathrm{MH}$ and $\mathrm{KS}$ conceived and designed the experiments. TN and $\mathrm{MH}$ infected the mice and collected the data. HK, RA, RW and KS performed and interpreted the QTL analysis. FK performed the analysis of environmental and experimental factors. SS and LL provided BXD mice for experimental studies. HK, RW and KS wrote the manuscript. All authors read and approved the final manuscript.

\section{Authors' information}

Tatiana Nedelko and Heike Kollmus contributed equally as first authors. Robert W. Williams and Klaus Schughart contributed equally as senior authors.

\section{Acknowledgments}

This work was supported by intra-mural grants from the HelmholtzAssociation (Program Infection and Immunity) and a research grant FluResearchNet (No. 01KI07137) from the German Ministry of Education and Research to KS and the virtual institute 'GeNeSys' funded by the Helmholtz Association. The funders have no role in study design, data collection and analysis, decision to publish, or preparation of the manuscript. Mice for these experiments were maintained by the animal caretakers of the Central Animal Facilities at the HZI. We wish to thank Christin Fricke for excellent technical assistance.

\section{Author details}

'Department of Infection Genetics, Helmholtz Centre for Infection Research and University of Veterinary Medicine Hannover, 38124, Braunschweig, Germany. ${ }^{2}$ Department of Bioinformatics and Statistics, Helmholtz Centre for Infection Research, Braunschweig, Germany. ${ }^{3}$ Department of Computer Science, Ostfalia University of Applied Sciences, Wolfenbüttel, Germany. ${ }^{4}$ Department of Anatomy and Neurobiology, University of Tennessee Health Science Center, Memphis, Tennessee, United States of America. ${ }^{5}$ Department of Molecular and Cellular Neurobiology, Neuroscience Campus Amsterdam, Amsterdam, VU, the Netherlands. ${ }^{6}$ Jiangsu Key Laboratory of Neuroregeneration, Nantong University, Nantong, China. ${ }^{7}$ Nycomed GmbH, Institute for Pharmacology and Preclinical Drug Safety,

Barsbuettel-Willinghusen, Germany.

\section{Received: 10 April 2012 Accepted: 10 August 2012}

Published: 20 August 2012

\section{References}

1. Johnson NP, Mueller J: Updating the accounts: global mortality of the 1918-1920 "Spanish" influenza pandemic. Bull Hist Med 2002, 76(1):105-115

2. Fauci AS: Seasonal and pandemic influenza preparedness: science and countermeasures. J Infect Dis 2006, 194(Suppl 2):S73-76.

3. Scriven J, McEwen R, Mistry S, Green C, Osman H, Bailey M, Ellis C: Swine flu: a Birmingham experience. Clin Med 2009, 9(6):534-538.

4. Yates L, Pierce M, Stephens S, Mill A, Spark P, Kurinczuk J, Valappil M, Brocklehurst $P$, Thomas S, Knight M: Influenza A/H1N1v in pregnancy: an investigation of the characteristics and management of affected women 
and the relationship to pregnancy outcomes for mother and infant Health Technol Assess 2010, 14(34):109-182.

5. Albright FS, Orlando P, Pavia AT, Jackson GG, Cannon-Albright LA: Evidence for a heritable predisposition to death due to influenza. J Infect Dis 2008, 197(1):18-24.

6. Gottfredsson M, Halldorsson BV, Jonsson S, Kristjansson M, Kristjansson K, Kristinsson KG, Love A, Blondal T, Viboud C, Thorvaldsson S, et al: Lessons from the past: familial aggregation analysis of fatal pandemic influenza (Spanish flu) in Iceland in 1918. Proc Natl Acad Sci U S A 2008, 105(4):1303-1308.

7. Horby P, Sudoyo H, Viprakasit V, Fox A, Thai PQ, Yu H, Davila S, Hibberd M, Dunstan SJ, Monteerarat $Y$, et al: What is the evidence of a role for host genetics in susceptibility to influenza A/H5N1? Epidemiol Infect 2010, 138(11):1-9.

8. Everitt AR, Clare S, Pertel T, John SP, Wash RS, Smith SE, Chin CR, Feeley EM, Sims JS, Adams DJ, et al: IFITM3 restricts the morbidity and mortality associated with influenza. Nature 2012, 484(7395):519-523.

9. Srivastava B, Blazejewska P, Hessmann M, Bruder D, Geffers R, Mauel S, Gruber AD, Schughart K: Host genetic background strongly influences the response to influenza a virus infections. PLOS ONE 2009, 4(3):e4857.

10. Trammell RA, Toth LA: Genetic susceptibility and resistance to influenza infection and disease in humans and mice. Expert Rev Mol Diagn 2008, 8(4):515-529.

11. Ding $M, L u L$, Toth $L A$ : Gene expression in lung and basal forebrain during influenza infection in mice. Genes Brain Behav 2008, 7(2):173-183.

12. Boon AC, DeBeauchamp J, Hollmann A, Luke J, Kotb M, Rowe S, Finkelstein D, Neale G, Lu L, Williams RW, et al: Host genetic variation affects resistance to infection with a highly pathogenic H5N1 influenza A virus in mice. J Virol 2009, 83(20):10417-10426.

13. Boon AC, Debeauchamp J, Krauss S, Rubrum A, Webb AD, Webster RG, McElhaney J, Webby RJ: Cross-reactive neutralizing antibodies directed against pandemic H1N1 2009 virus are protective in a highly sensitive DBA/2 influenza mouse model. J Virol 2010, 84(15):7662-7667.

14. Otte A, Sauter M, Alleva L, Baumgarte S, Klingel K, Gabriel G: Differential host determinants contribute to the pathogenesis of 2009 pandemic H1N1 and human H5N1 influenza A viruses in experimental mouse models. Am J Pathol 2011, 179(1):230-239.

15. Boon AC, Finkelstein D, Zheng M, Liao G, Allard J, Klumpp K, Webster R, Peltz G, Webby RJ: H5N1 influenza virus pathogenesis in genetically diverse mice is mediated at the level of viral load. MBio 2011, 2(5):pii: e00171-11.

16. Trammell RA: Liberati TA. Toth LA: Host genetic background and the innate inflammatory response of lung to influenza virus. Microbes Infect; 2011.

17. Pica N, lyer A, Ramos I, Bouvier NM, Fernandez-Sesma A, Garcia-Sastre A, Lowen AC, Palese P, Steel J: The DBA.2 mouse is susceptible to disease following infection with a broad, but limited, range of influenza $A$ and $B$ viruses. J Virol 2011, 85(23):5-12829.

18. Blazejewska P, Koscinski L, Viegas N, Anhlan D, Ludwig S, Schughart K: Pathogenicity of different PR8 influenza A virus variants in mice is determined by both viral and host factors. Virology 2011, 412(1):36-45.

19. Peirce $J$, Lu L, Gu J, Silver LM, Williams RW: A new set of BXD recombinant inbred lines from advanced intercross populations in mice. BMC Genet 2004, 5:7

20. Taylor BA, Wnek C, Kotlus BS, Roeme RN, MacTaggart T, Phillips SJ: Genotyping new BXD recombinant inbred mouse strains and comparison of BXD and consensus maps. Mamm Genome 1999, 10(4):335-348

21. Williams RW, Gu J, Qi S, Lu L: The genetic structure of recombinant inbred mice: high-resolution consensus maps for complex trait analysis. Genome Biol 2001, 2(11):RESEARCH0046.

22. Chesler EJ, Lu L, Wang J, Williams RW, Manly KF: WebQTL: rapid exploratory analysis of gene expression and genetic networks for brain and behavior. Nat Neurosci 2004, 7(5):485-486.

23. Alberts R, Srivastava B, Wu H, Viegas N, Geffers R, Klawonn F, Novoselova N, Do Valle TZ, Panthier JJ, Schughart K: Gene expression changes in the host response between resistant and susceptible inbred mouse strains after influenza A infection. Microbes Infect 2010, 12(4):309-318.

24. Ziebarth JD, Cook MN, Wang X, Williams RW, Lu L, Cui Y: Treatment- and population-dependent activity patterns of behavioral and expression
QTLs. PLOS ONE 2012, 7(2):e31805

25. Alberts R, Schughart K: QTLminer: identifying genes regulating quantitative traits. BMC Bioinformatics 2010, 11:516.

26. Alberts R, Lu L, Williams RW, Schughart K: Genome-wide analysis of the mouse lung transcriptome reveals novel molecular gene interaction networks and cell-specific expression signatures. Respir Res 2011, 12:61.

27. Zhirnov OP, Matrosovich TY, Matrosovich MN, Klenk HD: Aprotinin, a protease inhibitor, suppresses proteolytic activation of pandemic H1N1v influenza virus. Antivir Chem Chemother 2011, 21(4):169-174.

28. Okumura Y, Takahashi E, Yano M, Ohuchi M, Daidoji T, Nakaya T, Bottcher $E_{\text {, }}$ Garten W, Klenk HD, Kido H: Novel type II transmembrane serine proteases, MSPL and TMPRSS13, proteolytically activate membrane fusion activity of hemagglutinin of highly pathogenic avian influenza viruses and induce their multicycle replication. J Viro 2010, 84(10):5089-5096.

29. Bottcher-Friebertshauser E, Freuer C, Sielaff F, Schmidt S, Eickmann M, Uhlendorff J, Steinmetzer T, Klenk HD, Garten W: Cleavage of influenza virus hemagglutinin by airway proteases TMPRSS2 and HAT differs in subcellular localization and susceptibility to protease inhibitors. $J$ Viro 2010, 84(11):5605-5614.

30. Bertram S, Glowacka I, Blazejewska P, Soilleux E, Allen P, Danisch S, Steffen I, Choi SY, Park Y, Schneider H, et al: TMPRSS2 and TMPRSS4 facilitate trypsin-independent spread of influenza virus in Caco-2 cells. J Virol 2010, 84(19):10016-10025.

31. Chaipan C, Kobasa D, Bertram S, Glowacka I, Steffen I, Tsegaye TS, Takeda M, Bugge TH, Kim S, Park Y, et al: Proteolytic activation of the 1918 influenza virus hemagglutinin. J Virol 2009, 83(7):3200-3211

32. Steinhauer DA: Role of hemagglutinin cleavage for the pathogenicity of influenza virus. Virology 1999, 258(1):1-20.

33. Boivin GA, Pothlichet J, Skamene E, Brown EG, Loredo-Osti JC, Sladek R, Vidal SM: Mapping of clinical and expression quantitative trait loci in a sex-dependent effect of host susceptibility to mouse-adapted influenza H3N2/HK/1/68. J Immunol 2012,

34. Bottomly D, Ferris MT, Aicher LD, Rosenzweig E, Whitmore A, Aylor DL, Haagmans BL, Gralinski LE, Bradel-Tretheway BG, Bryan JT, et al: Expression quantitative trait Loci for extreme host response to influenza a in pre-collaborative cross mice. G3 (Bethesda) 2012, 2(2):213-221.

35. Krishnamoorthy J, Mounir Z, Raven JF, Koromilas AE: The elF2alpha kinases inhibit vesicular stomatitis virus replication independently of elF2alpha phosphorylation. Cell Cycle 2008, 7(15):2346-2351.

36. Thakur SA, Zalinger Z, Johnson TR, Imani F: PKR is a novel mediator of CD40 signaling and plays a critical role in modulating immunoglobulin expression during RSV infection. Clin Vaccine Immunol 2011, 18(12):2060-2066.

37. Bergmann M, Garcia-Sastre A, Carnero E, Pehamberger H, Wolff K, Palese P, Muster T: Influenza virus NS1 protein counteracts PKR-mediated inhibition of replication. J Virol 2000, 74(13):6203-6206.

38. Ludlow A, Yee KO, Lipman R, Bronson R, Weinreb P, Huang X, Sheppard D Lawler J: Characterization of integrin beta 6 and thrombospondin-1 double-null mice. J Cell Mol Med 2005, 9(2):421-437.

39. Hogmalm A, Sheppard D, Lappalainen U, Bry K: beta6 Integrin subunit deficiency alleviates lung injury in a mouse model of bronchopulmonary dysplasia. Am J Respir Cell Mol Biol 2010, 43(1):88-98.

40. Yoneyama M, Kikuchi M, Matsumoto K, Imaizumi T, Miyagishi M, Taira K, Foy E, Loo YM, Gale M Jr, Akira $S$, et al: Shared and unique functions of the DExD/H-box helicases RIG-I, MDA5, and LGP2 in antiviral innate immunity. J Immunol 2005, 175(5):2851-2858.

41. Choi MK, Wang Z, Ban T, Yanai H, Lu Y, Koshiba R, Nakaima Y, Hangai S, Savitsky D, Nakasato M, et al: A selective contribution of the RIG-I-like receptor pathway to type I interferon responses activated by cytosolic DNA. Proc Natl Acad Sci U S A 2009, 106(42):17870-17875.

42. Gitlin L, Benoit L, Song C, Cella M, Gilfillan S, Holtzman MJ, Colonna M: Melanoma differentiation-associated gene 5 (MDA5) is involved in the innate immune response to Paramyxoviridae infection in vivo. PLoS Pathog 2010, 6(1):e1000734.

43. Gitlin L, Barchet W, Gilfillan S, Cella M, Beutler B, Flavell RA, Diamond MS, Colonna M: Essential role of mda-5 in type I IFN responses to polyriboinosinic:polyribocytidylic acid and encephalomyocarditis picornavirus. Proc Natl Acad Sci U S A 2006, 103(22):8459-8464.

44. Kato H, Takeuchi O, Sato S, Yoneyama M, Yamamoto M, Matsui K, 
Uematsu S, Jung A, Kawai T, Ishii K, et al: Differential roles of MDA5 and RIG-I helicases in the recognition of RNA viruses. Nature 2006 441(7089):101-105.

45. Andrews W, Barber M, Hernadez-Miranda LR, Xian J, Rakic S, Sundaresan V, Rabbitts TH, Pannell R, Rabbitts P, Thompson H, et al: The role of Slit-Robo signaling in the generation, migration and morphological differentiation of cortical interneurons. Dev Biol 2008, 313(2):648-658.

46. Long H, Sabatier C, Ma L, Plump A, Yuan W, Ornitz DM, Tamada A Murakami F, Goodman CS, Tessier-Lavigne M: Conserved roles for Slit and Robo proteins in midline commissural axon guidance. Neuron 2004 42(2):213-223

47. Xian J, Clark KJ, Fordham R, Pannell R, Rabbitts TH, Rabbitts PH: Inadequate lung development and bronchial hyperplasia in mice with a targeted deletion in the Dutt1/Robo1 gene. Proc Natl Acad Sci U S A 2001, 98(26):15062-15066.

48. Clark K, Hammond E, Rabbitts P: Temporal and spatial expression of two isoforms of the Dutt1/Robo1 gene in mouse development. FEBS Lett 2002, 523(1-3):12-16.

49. Zschiedrich I, Hardeland U, Krones-Herzig A, Berriel Diaz M, Vegiopoulos A, Muggenburg J, Sombroek D, Hofmann TG, Zawatzky R, Yu X, et al: Coactivator function of RIP140 for NFkappaB/RelA-dependent cytokine gene expression. Blood 2008, 112(2):264-276.

50. Ho PC, Chang KC, Chuang YS, Wei LN: Cholesterol regulation of receptorinteracting protein 140 via microRNA-33 in inflammatory cytokine production. FASEB J 2011, 25(5):1758-1766.

51. Janeway CA, Travers P, Walport MJ, Shlomchik MJ: Immunobiology: The Immune System in Health and Disease. New York: Garland Science; 2005.

52. Ovsyannikova IG, Vierkant RA, Pankratz VS, Jacobson RM, Poland GA: Extended LTA, TNF, LST1 and HLA gene haplotypes and their association with rubella vaccine-induced immunity. PLOS ONE 2010, 5(7):e11806.

53. Schiller C, Nitschke MJ, Seidl A, Kremmer E, Weiss EH: Rat monoclonal antibodies specific for LST1 proteins. Hybridoma (LarChmt) 2009, 28(4):281-286

54. Mulcahy H, O'Rourke KP, Adams C, Molloy MG, O'Gara F: LST1 and NCR3 expression in autoimmune inflammation and in response to IFN-gamma, LPS and microbial infection. Immunogenetics 2006, 57(12):893-903.

55. Kilding R, lles MM, Timms JM, Worthington J, Wilson AG: Additional genetic susceptibility for rheumatoid arthritis telomeric of the DRB1 locus. Arthritis Rheum 2004, 50(3):763-769.

56. Lavi S, McConnell JP, Rihal CS, Prasad A, Mathew V, Lerman LO, Lerman A: Local production of lipoprotein-associated phospholipase A2 and lysophosphatidylcholine in the coronary circulation: association with early coronary atherosclerosis and endothelial dysfunction in humans. Circulation 2007, 115(21):2715-2721.

57. Kim JY, Hyun YJ, Jang Y, Lee BK, Chae JS, Kim SE, Yeo HY, Jeong TS, Jeon DW, Lee JH: Lipoprotein-associated phospholipase A2 activity is associated with coronary artery disease and markers of oxidative stress: a case-control study. Am J Clin Nutr 2008, 88(3):630-637.

58. Kostopanagiotou G, Avgerinos E, Costopanagiotou C, Arkadopoulos N Andreadou I, Diamantopoulou K, Lekka M, Smyrniotis V, Nakos G: Acute lung injury in a rat model of intestinal ischemia-reperfusion: the potential time depended role of phospholipases A(2). J Surg Res 2008, 147(1):108-116.

59. Sutton BS, Crosslin DR, Shah SH, Nelson SC, Bassil A, Hale AB, Haynes C, Goldschmidt-Clermont PJ, Vance JM, Seo D, et al: Comprehensive genetic analysis of the platelet activating factor acetylhydrolase (PLA2G7) gene and cardiovascular disease in case-control and family datasets. Hum Mol Genet 2008, 17(9):1318-1328

60. Wang Q, Hao Y, Mo X, Wang L, Lu X, Huang J, Cao J, Li H, Gu D: PLA2G7 gene polymorphisms and coronary heart disease risk: a meta-analysis. Thromb Res 2010, 126(6):498-503.

61. Sadegh-Nasseri S, Chen M, Narayan K, Bouvier M: The convergent roles of tapasin and HLA-DM in antigen presentation. Trends Immunol 2008, 29(3):141-147.

62. Turnquist HR, Petersen JL, Vargas SE, Mcllhaney MM, Bedows E, Mayer WE, Grandea AG 3rd, Van Kaer L, Solheim JC: The Ig-like domain of tapasin influences intermolecular interactions. J Immunol 2004, 172(5):2976-2984.

63. Garbi N, Tiwari N, Momburg F, Hammerling GJ: A major role for tapasin as a stabilizer of the TAP peptide transporter and consequences for MHC class I expression. Eur J Immunol 2003, 33(1):264-273.
64. Williams AP, Peh CA, Purcell AW, McCluskey J, Elliott T: Optimization of the MHC class I peptide cargo is dependent on tapasin. Immunity 2002, 16(4):509-520

65. Raghuraman G, Lapinski PE, Raghavan M: Tapasin interacts with the membrane-spanning domains of both TAP subunits and enhances the structural stability of TAP1 x TAP2 Complexes. J Biol Chem 2002, 277(44):41786-41794.

66. Rufer E, Leonhardt RM, Knittler MR: Molecular architecture of the TAP-associated MHC class I peptide-loading complex. J Immunol 2007 179(9):5717-5727.

67. Fukuda A, Tokonabe S, Hamada M, Matsumoto M, Tsukui T, Nogi Y, Hisatake K: Alleviation of PC4-mediated transcriptional repression by the ERCC3 helicase activity of general transcription factor TFIIH. J Biol Chem 2003, 278(17):14827-14831.

68. Kim YK, Bourgeois CF, Pearson R, Tyagi M, West MJ, Wong J, Wu SY, Chiang CM, Karn J: Recruitment of TFIIH to the HIV LTR is a rate-limiting step in the emergence of HIV from latency. EMBO J 2006 25(15):3596-3604.

69. Briggs FB, Goldstein BA, McCauley JL, Zuvich RL, De Jager PL, Rioux JD, Ivinson AJ, Compston A, Hafler DA, Hauser SL, et al: Variation within DNA repair pathway genes and risk of multiple sclerosis. Am J Epidemio/ 2010 172(2):217-224.

70. Young LR, Borchers MT, Allen HL, Gibbons RS, McCormack FX: Lungrestricted macrophage activation in the pearl mouse model of Hermansky-Pudlak syndrome. J Immunol 2006, 176(7):4361-4368.

71. Sammon JW: A nonlinear mapping for data structure analysis. IEEE Transactions on Computers 1969, 18:401-409.

72. Ljungberg K, Holmgren S, Carlborg O: Simultaneous search for multiple QTL using the global optimization algorithm DIRECT. Bioinformatics 2004, 20(12):1887-1895.

73. Wang X, Agarwala R, Capra J, Chen Z, Church D, Ciobanu D, Li Z, Lu L, Mozhui $K$, Mulligan M, et al: High-throughput sequencing of the DBA/2J mouse genome. BMC Bioinformatics 2010, 11(Suppl 4):07. doi:10.1186/14712105-1111-S1184-01187.

doi:10.1186/1471-2164-13-411

Cite this article as: Nedelko et al:: Distinct gene loci control the host response to influenza $\mathrm{H} 1 \mathrm{~N} 1$ virus infection in a time-dependent manner. BMC Genomics 2012 13:411.

\section{Submit your next manuscript to BioMed Central and take full advantage of:}

- Convenient online submission

- Thorough peer review

- No space constraints or color figure charges

- Immediate publication on acceptance

- Inclusion in PubMed, CAS, Scopus and Google Scholar

- Research which is freely available for redistribution 